\title{
Process Technologies and Projects for BioLPG
}

\author{
Eric Johnson $\mathbb{D}$ \\ Atlantic Consulting, 8136 Gattikon, Switzerland; ejohnson@ecosite.co.uk; Tel.: +41-44-772-1079
}

Received: 8 December 2018; Accepted: 9 January 2019; Published: 15 January 2019

\begin{abstract}
Liquified petroleum gas (LPG)—currently consumed at some 300 million tonnes per year-consists of propane, butane, or a mixture of the two. Most of the world's LPG is fossil, but recently, BioLPG has been commercialized as well. This paper reviews all possible synthesis routes to BioLPG: conventional chemical processes, biological processes, advanced chemical processes, and other. Processes are described, and projects are documented as of early 2018. The paper was compiled through an extensive literature review and a series of interviews with participants and stakeholders. Only one process is already commercial: hydrotreatment of bio-oils. Another, fermentation of sugars, has reached demonstration scale. The process with the largest potential for volume is gaseous conversion and synthesis of two feedstocks, cellulosics or organic wastes. In most cases, BioLPG is produced as a byproduct, i.e., a minor output of a multi-product process. BioLPG's proportion of output varies according to detailed process design: for example, the advanced chemical processes can produce BioLPG at anywhere from 0-10\% of output. All these processes and projects will be of interest to researchers, developers and LPG producers/marketers.
\end{abstract}

Keywords: Liquified petroleum gas (LPG); BioLPG; biofuels; process technologies; alternative fuels

\section{Introduction}

Liquified petroleum gas (LPG) is a major fuel for heating and transport, with a current global market of around 300 million tonnes per year. As are all fossil fuels, LPG is under pressure to decarbonise. To this end, its main fossil competitors have introduced bio-alternatives: biodiesel for diesel; bioethanol for gasoline; and biogas or biomethane for natural gas. LPG has followed suit in 2017-18 with the introduction of BioLPG [1]. Based on discussions with the industry and detailed searches of the commercial literature, the author estimates current worldwide production of BioLPG at about 200 thousand tonnes per year. Nearly all of this is produced via hydrogenation of animal and plant oils, much of those being wastes.

There is great interest among the LPG industry and decarbonisation-proponents to expand production volumes of BioLPG. This could happen by increasing capacity for hydrogenation and by commercialization of other process routes to BioLPG. This paper aims to support that process by giving researchers and process-developers an initial roadmap: it reviews all possible processes and known projects for producing BioLPG. The contents were compiled through an extensive literature review and interviews with participants and stakeholders. The paper should be of interest to researchers, developers, and LPG producers/marketers.

BioLPG can be produced by seven general processes (Table 1). Two of them (in green) are most promising:

- Hydrotreating of bio-oils is already producing 200 kilotonnes of biopropane, with some additions planned;

- Gaseous conversion and synthesis of cellulosics and organic waste does not yet generate any BioLPG, but BioLPG production this way is technically feasible, is under exploration and the potential feedstock availability is huge. 
Dehydrogenation (in yellow) offers some potential, mainly in the use of fluid catalytic crackers to process bio-oils and make some byproduct biopropane. Glycerine also can be dehydrogenated, and this is being explored. Fermentation already is producing small amounts of biobutylene and planning in underway for commercial production.

Fermentation (in grey) to biopropane has been proven at laboratory scale, but does not seem to be progressing further. The two other biological process (in brown) classes, hydrolysis and fermentation and digestion, do not offer serious promise of generating BioLPG. Neither does liquid conversion and synthesis (in brown), which technically is not all that different than gaseous conversion and synthesis, but attracts significantly less attention from developers.

Table 1. Feedstock-process summary for BioLPG.

\begin{tabular}{cccc}
\hline Feedstock & Process Class & $\begin{array}{c}\text { Product/ } \\
\text { Byproduct }\end{array}$ & Technical Readiness \\
\hline Bio-oil & Hydrotreating & By & Commercial \\
\hline $\begin{array}{c}\text { Bio-oil } \\
\text { Glycerine }\end{array}$ & Dehydrogenation & $\begin{array}{c}\text { By } \\
\text { Pro }\end{array}$ & $\begin{array}{c}\text { Demonstration } \\
\text { Pilot }\end{array}$ \\
\hline Sugars & Fermentation & Pro & Demonstration \\
\hline Cellulosics & Hydrolysis and fermentation & - & Concept \\
\hline Wet wastes & Digestion & - & Concept \\
\hline $\begin{array}{c}\text { Cellulosics } \\
\text { Organic waste }\end{array}$ & Gaseous conversion and synthesis & By & $\begin{array}{c}\text { Demonstration } \\
\text { Concept }\end{array}$ \\
\hline $\begin{array}{c}\text { Cellulosics } \\
\text { Organic waste }\end{array}$ & Liquid conversion and synthesis & By & Concept \\
\hline
\end{tabular}

In most cases, BioLPG is produced as a byproduct, or perhaps it could be called a 'minor' output of a multi-product process. Moreover, BioLPG's proportion of output can vary according to detailed process design: for example, the advanced chemical processes can produce BioLPG at anywhere from $0-10 \%$ of output.

There are four process types that lead to BioLPG: conventional chemical, biological, advanced chemical, and other. These have been used to organise process classes and individual processes that are presented in this paper. Each of these is covered in a section, subsections are devoted to the individual processes and the projects pursuing those. Each process type is described, and then the individual processes and projects are described by feedstock type. All known BioLPG processes are covered.

Project is defined broadly. To projects we have applied the following classifications of 'technology readiness' that are widely used in the process industries:

- Concept

- Laboratory

- Pilot

- Demonstration

- First commercial

- Commercial

Some projects have been developed explicitly for licensing to third-party owner/operators.

\section{Conventional Chemical Processes and Projects}

These are synthetic processes that are well-known and commercially well-established: hydrotreatment and dehydration. Hydrotreatment is, to date, the only significant source of BioLPG. Dehydration produces negligible BioLPG so far, but could be expanded. 
The biggest market trend is that of conventional refiners making BioLPG by co-processing bio-oils together with petroleum intermediates, typically at a blend of around 30\% bio and 70\% fossil. This results in a mixed stream of diesel/biodiesel and another, smaller stream of mostly BioLPG. Co-processing can be done in existing hydrotreaters or hydrocrackers that undergo some modifications. At least one refiner is experimenting with co-processing bio-oil in a fluid catalytic cracker: again, BioLPG comes out as a byproduct to biodiesel.

\subsection{Hydrotreatment}

Hydrotreatment, or hydrogenation, is the only significant source today of BioLPG production, an estimated 200 kilotonnes per year. About 100 kilotonnes of the biopropane produced is extracted for sale as BioLPG, the rest is used as a process fuel. None of the production is 'on-purpose', i.e., the biopropane is an unavoidable byproduct. The 'on-purpose' product is HVO biodiesel, (HVO stands for hydrogenated vegetable oil), often called renewable diesel. By weight the ratio of biodiesel:biopropane output is about 9-10:1.

Finland-based Neste is the largest producer of BioLPG (biopropane), making about 90 kilotonnes/ year at three locations. Italian oil major ENI is second-largest, making a 20 kilotonnes/year and planning another 20-kt project. Projects of all types number to about 40, about 25 of those are commercial or first-commercial operations, and about 10 of those are believed to be in operation. All of them convert bio-oils to biodiesel and produce biopropane as a byproduct.

Neste and ENI, plus two US producers operate 'exclusive' biodiesel:biopropane plants, i.e., they run exclusively on bio feedstocks. Another six producers are conventional oil refiners that are co-processing bio-oils together with petroleum streams at approximately a 30:70 ratio by weight. This produces a mixed stream of diesel/biodiesel and propane/biopropane. Other refiners are known to be investigating this opportunity.

Most if not all biopropane producers hydrotreat some bio fatty acids along with bio-oils. The fatty acids convert to biodiesel, but they do not yield any biopropane. The hydrotreatment process is well understood and is available from several vendors for license. Other feedstocks than bio-oils could be hydrotreated to synthesise biopropane or biobutane. None of these are close to commercialisation.

\subsubsection{Process Description}

Hydrotreatment is a reaction of a hydrocarbon stream with hydrogen, usually in the presence of a catalyst, at moderate temperature and pressure. It is applied mainly in two ways: to hydrogenate unsaturated bonds, to remove oxygen or to reduce inorganic components such as nitrogen or sulphur. Depending on conditions, the process can cause a variety of reactions can occur (Figure 1). In the context of BioLPG, the most important of these are decarboxylation, hydrodeoxygenation and hydrogenation $[2,3]$.

With regard to BioLPG, hydrotreatment goes by a variety of names. The process for converting triglyceride bio-oils to biodiesel and biopropane is often called ' $\mathrm{HVO}^{\prime}$ ', which comes from 'hydrotreated vegetable oil' or 'hydrogenated vegetable oil'. Other names for it include: 'HDRD' for 'hydrogenation derived renewable diesel', 'non ester renewable diesel', 'renewable hydrocarbon diesel', 'HBD' for 'hydro-generated biodiesel' [4] and 'HEFA' for 'hydroprocessed esters and fatty acids'. Another generic name would be 'hydrogenation', however, this is usually linked to the manufacturing of margarine, so hydrotreatment seems to be the best generic choice. 


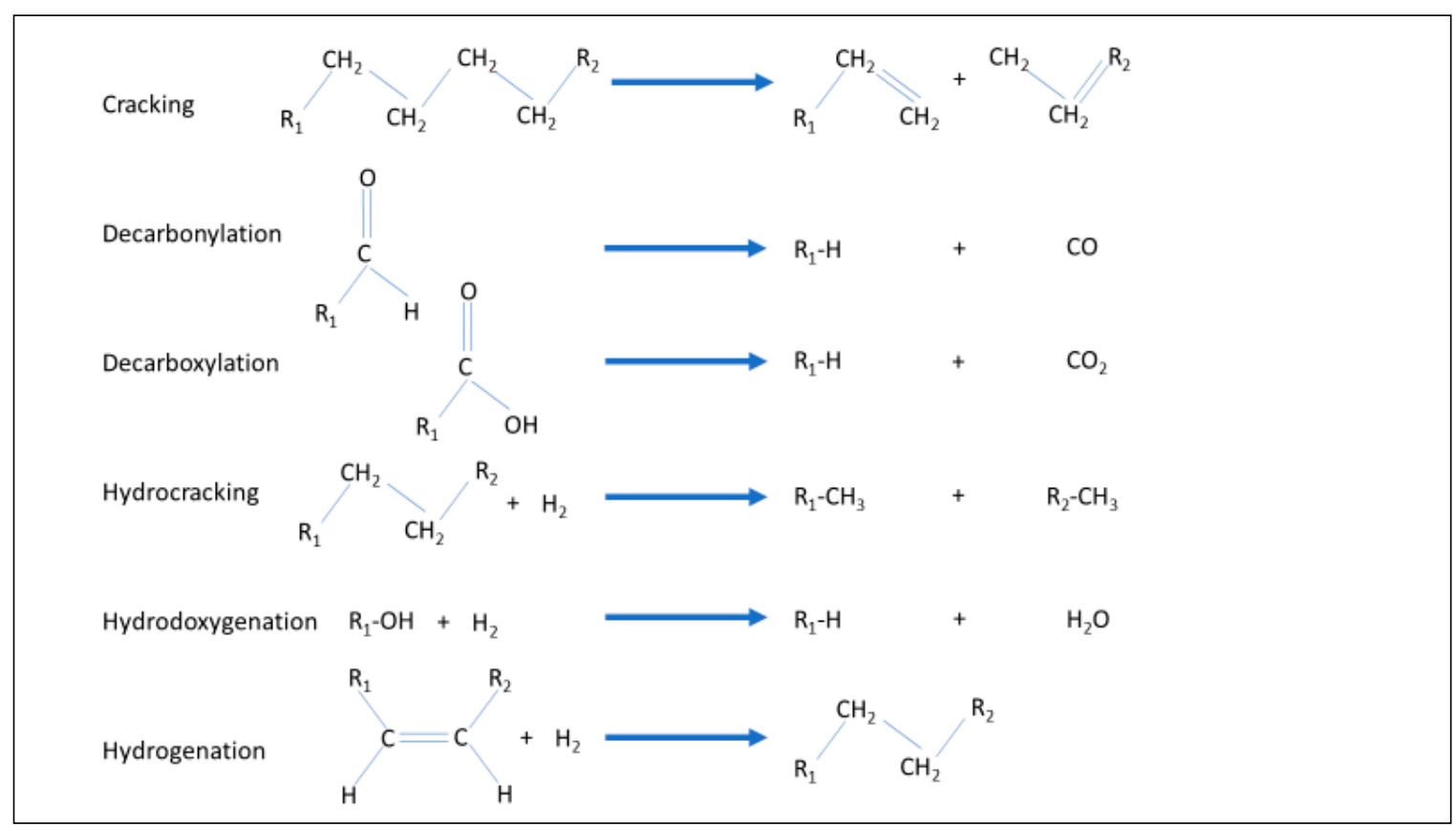

Figure 1. Reactions of hydrotreating.

\subsubsection{Technical Readiness}

Hydrotreating in general is a mature, commercial process. It is widely used in petroleum refineries, particularly to remove sulphur from refined products. Refiners also practise a more severe form of hydrogenation, at higher temperatures and pressures, called hydrocracking (Figure 1). This cracks or splits longer hydrocarbons into shorter ones. Hydrotreating is also applied to make margarine: liquid vegetable oils are saturated by hydrotreating, to create a solid, hydrogenated vegetable oil.

Hydrotreating to create biodiesel and biopropane is less mature, maybe 20 years old, but still well established. Nearly 30 commercial or first-commercial projects exist worldwide (Table 2), and several vendors offer a version of the biodiesel/biopropane process for license.

\subsubsection{Process Developers/Licensors}

Six companies offer a biodiesel hydrotreatment process for license (Table 2). This report reckons engineering-contractor UOP and ENI as one company, in this respect, because they jointly offer a process. Petrobras is not on the list. Although the Brazilian oil company has developed its own process, called H-BIO, it is not clear whether this is available for license to third parties.

\subsubsection{Projects and Production}

Several feedstocks can be hydrotreated to create BioLPG: bio-oils, propylene, butylenes, and dimethyl ether (DME). The only commercially significant one is bio-oil. In turn, it is the only significant source of BioLPG.

\section{Bio-Oils}

This is the only significant source today of BioLPG production, an estimated 200 kilotonnes per year. About 100 kilotonnes of the biopropane produced is extracted for sale as BioLPG, the rest is used as a process fuel. None of the production is 'on-purpose', i.e., the biopropane is an unavoidable byproduct. The 'on-purpose' product is HVO biodiesel, often called renewable diesel. By weight, the ratio of biodiesel:biopropane output is about 9-10:1. 
Biopropane is a byproduct, because bio-oils (natural oils from animals and plants) all come in the form of a triglyceride. These (Figure 2) are long-chain hydrocarbons (in yellow) connected by an ester linkage (where yellow and brown meet) to a three-carbon (in brown) backbone.

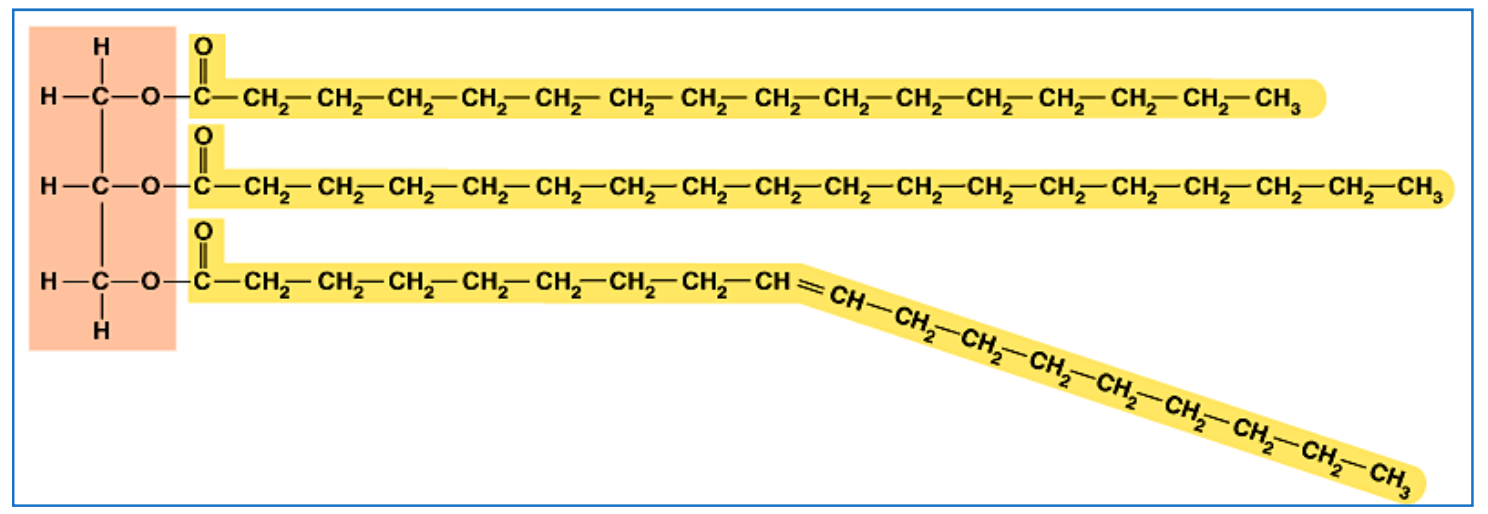

Figure 2. A typical triglyceride (natural oil or fat).

Hydrogen is reacted with the triglycerides at temperature and pressure in the presence of catalysts to hydrogenate the double bonds in the fatty acid chains in the triglyceride. Next, the glycerol backbone is broken and the oxygen removed, leaving paraffinic n-alkanes— the biodiesel—and the hydrogenated three-carbon backbone, biopropane [3] (Figure 3).

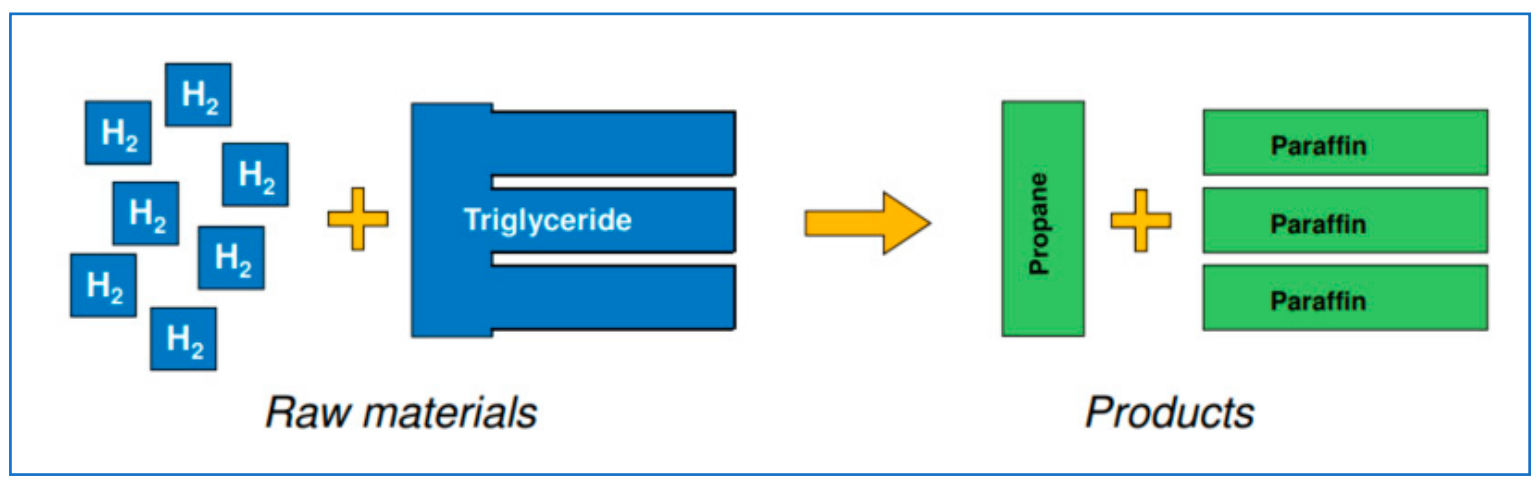

Figure 3. A schematic view of the process, bio-oil to biodiesel and biopropane.

Two Feedstock Approaches: Exclusive Bio and Co-Process

For hydrotreating bio-oils, there are two approaches to feedstocks.

One is to process only bio feedstocks. Neste and ENI, plus two US producers, Renewable Energy Group and Valero, do this. They operate 'exclusive' biodiesel/biopropane plants that run exclusively on bio feedstocks.

Another is to co-process bio and fossil feedstocks. Five refiners-Spain's CEPSA, Portugal's Galp, Ireland's Irving Oil, Sweden's PREEM and Spain's Repsol-are conventional oil refiners that are co-processing petroleum streams together with bio-oils at approximately a 70:30 ratio by weight. This produces a mixed stream of diesel/biodiesel and propane:biopropane. Other refiners are known to be investigating this opportunity: Naftna Industrija Srbije at Novi Sad, Serbia [2], ÖMV and PKN Orlen. They are using existing refinery hydrotreaters that have been modified to handle bio-oils. Modifications are required, because bio-oils are oxygenates (the ester linkage), so they react differently to their petroleum counterparts [5,6]. PREEM is known to have applied Haldor Topsoe's Hydroflex process for its modifications. Total is believed to have used the VEGAN process from Axens/IFP (Institut Francais du Petrole). 
Fatty Acids (Do Not Make Biopropane)

Fatty acids are also suitable feedstocks to make HVO biodiesel, but not for BioLPG. If fatty acids were to displace bio-oils in hydrogenation processes, biopropane production would disappear.

Most of the commercial projects making HVO biodiesel (Table 2) use bio-oils as feedstocks. Because these are triglycerides, they also automatically produce biopropane. However, some of the projects also take fatty acids as feedstock. The fatty acids usually are mixed into the bio-oil, but in some cases the feedstock is all fatty acid:

- PFAD (palm fatty acid distillate) — crude palm oil has a fraction of fatty acids that usually is removed by distillation and sold separately.

- Tall oil-this comes from wood and is produced as a byproduct of pulping (to make paper). Despite its name, it is not actually an oil, but a collection of fatty acids.

Fatty acids are similar to triglycerides in that they have a long chain hydrocarbon connected to a carboxyl group, but the carboxyl group stops there-it is the acid. It does not connect to a three-carbon backbone that could be converted to biopropane.

Just one HVO biodiesel producer (Table 2) is known to use only fatty acid feedstock: UPM, a forest-products company at its plant in Lappeenranta, Finland. The plant takes tall oil from a nearby pulping operation. The HVO production of PREEM in its refinery in Gothenburg, Sweden, reportedly ran only on tall oil when it began operations, but has since moved to triglycerides (to what fraction is unclear). Other HVO producers take some fraction of fatty acids along with bio-oils, often as acid-oil mixtures. These mixtures tend to be cheaper, are inedible to humans, and sometimes classified as wastes (which leads to a lower carbon footprint).

Propylene and Butylene

Biopropylene could be hydrotreated to biopropane, and biobutylene could be hydrotreated to biobutane. While these are chemically feasible options, they are unlikely to attract much commercial interest, because either biopropylene or biobutylene could be sold on their own, without further processing.

Bio-olefins (ethylene, propylene, butylene) are not plentiful. Some bio-ethylene is produced in Brazil (from sugarcane), and this is sold to make bio-polyethylene. Braskem, the Brazilian chemical company, has investigated making bio-propylene, but has mothballed the idea as uneconomic. Bio-butylene is being produced in small quantities, but this is sold as such and not committed further to hydrotreating.

\section{DME (Dimethyl Ether)}

Japan's University of Kitakyushu has developed a laboratory-scale process for the conversion of DME to LPG by hydrogenation [7].

This could be done using bio-DME, to yield BioLPG. Bio-DME can be produced by catalytic dehydration of bio-methanol. Bio-DME can also be made from bio-syngas, i.e., gasified cellulosics or organic wastes. 
Table 2. Hydrotreatment projects for BioLPG, by technological readiness.

\begin{tabular}{|c|c|c|c|c|c|c|c|c|c|c|c|}
\hline Owner/Operator & Country & Location & Feedstock(s) & Process & $\begin{array}{l}\text { Process } \\
\text { Licensor }\end{array}$ & $\begin{array}{l}\text { Prime } \\
\text { Product }\end{array}$ & $\begin{array}{l}\text { Prime } \\
\text { Product } \\
\text { Capacity } \\
\text { kt/y }\end{array}$ & $\begin{array}{l}\text { Is Biopropane } \\
\text { Extracted? }\end{array}$ & $\begin{array}{c}\text { Bioprop Capacity } \\
\text { kt/y (These Have } \\
\text { Been Estimated from } \\
\text { Biodiesel Capacities.) }\end{array}$ & Status 2018 & Source \\
\hline \multicolumn{12}{|c|}{ COMMERCIAL } \\
\hline AltAir Fuels & USA & Paramount, $\mathrm{CA}$ & Tallow & Hydrocracker & UOP & Biodiesel & 130 & No & 7 & Operating & http://altairfuels.com/ \\
\hline BP & AUS & Bulwer Island & Bio oil & $\mathrm{HVO}$ & & Biodiesel & & No & 3 & Shut down & {$[8]$} \\
\hline CEPSA & ES & Tenerife & $\begin{array}{l}\text { UCO (used } \\
\text { cooking oil) }\end{array}$ & $\begin{array}{l}\text { Hydrotreater? } \\
\text { Co-process }\end{array}$ & & Biodiesel & & ? & & Operating & Author research \\
\hline CEPSA & ES & $\begin{array}{c}\text { Huelva } \\
\text { Algeciras-San } \\
\text { Roque }\end{array}$ & Bio oil & $\begin{array}{l}\text { Hydrotreater? } \\
\text { Co-process }\end{array}$ & & Biodiesel & 180 & ? & & Operating & Author research \\
\hline Eni & I & Porto Marghera & Bio oil & $\mathrm{HVO}$ & UOP/ENI & Biodiesel & 580 & Yes & 20 & Operating & {$[8]$} \\
\hline Eni & I & Gela, Sicily & Bio oil & HVO & UOP/ENI & Biodiesel & 500 & & & $\begin{array}{l}\text { Startup later in } \\
\text { year? }\end{array}$ & Author research \\
\hline Galp & $\mathrm{P}$ & Sines & Bio oil & $\begin{array}{l}\text { Hydrotreater } \\
\text { Co-process }\end{array}$ & & Biodiesel & 250 & & & & Author research \\
\hline $\begin{array}{l}\text { Irving Oil (former } \\
\text { ConocoPhillips) }\end{array}$ & IE & Whitegate & Soybean oil & $\begin{array}{l}\text { Hydrogenation, } \\
\text { co-processing }\end{array}$ & ConocoPhillips & Biodiesel & 46 & $\begin{array}{l}\text { Possible, but } \\
\text { company says is } \\
\text { 'technically } \\
\text { difficult'' }\end{array}$ & 3.22 & Operating & [8] \\
\hline Neste Oil & $\mathrm{NL}$ & Rotterdam & Bio oil & $\mathrm{HVO}$ & Neste-Jacobs & Biodiesel & 1000 & yes & 40 & Operating & [8] \\
\hline Neste Oil & $\mathrm{SF}$ & Porvoo & Bio oil & $\mathrm{HVO}$ & Neste-Jacobs & Biodiesel & 380 & Yes? & 10 & Operating & {$[8]$} \\
\hline Petrobras & $\mathrm{P}$ & & Bio oil & & & Biodiesel & & & & ? & Author research \\
\hline PREEM & $\mathrm{s}$ & Gothenburg & $\begin{array}{l}\text { Tall oil, now also } \\
\text { triglycerides }\end{array}$ & $\begin{array}{l}\text { Hydrogenation, } \\
\text { co-processing }\end{array}$ & Haldor-Topsoe & Biodiesel & 300 & $\begin{array}{l}\text { Yes, sold to } \\
\text { Kosan Gas }\end{array}$ & No, tall oil? & $\begin{array}{l}\text { Operating } \\
\text { Capacity } \\
\text { addition } \\
\text { planned }\end{array}$ & Author research \\
\hline $\begin{array}{l}\text { Renewable Energy } \\
\text { Group (former } \\
\text { Dynamic Fuels) }\end{array}$ & USA & Geismar, LA & $\begin{array}{l}\text { High and low } \\
\text { FFA (free fatty } \\
\text { acid) feedstocks, } \\
\text { heavy on tallow }\end{array}$ & HVO & Syntroleum & Biodiesel & 270 & & 1.3 & & [8] \\
\hline
\end{tabular}


Table 2. Cont.

\begin{tabular}{|c|c|c|c|c|c|c|c|c|c|c|c|}
\hline Owner/Operator & Country & Location & Feedstock(s) & Process & $\begin{array}{l}\text { Process } \\
\text { Licensor }\end{array}$ & $\begin{array}{l}\text { Prime } \\
\text { Product }\end{array}$ & $\begin{array}{l}\text { Prime } \\
\text { Product } \\
\text { Capacity } \\
\text { kt/y }\end{array}$ & $\begin{array}{l}\text { Is Biopropane } \\
\text { Extracted? }\end{array}$ & $\begin{array}{c}\text { Bioprop Capacity } \\
\text { kt/y (These Have } \\
\text { Been Estimated from } \\
\text { Biodiesel Capacities.) }\end{array}$ & Status 2018 & Source \\
\hline Repsol & ES & $\begin{array}{l}\text { La Coruña, } \\
\text { Tarragona, } \\
\text { Bilbao and } \\
\text { Cartagena }\end{array}$ & Palm oil & $\begin{array}{l}\text { Hydrogenation, } \\
\text { co-processing }\end{array}$ & & Biodiesel & 60 & starting 2018 & & & Author research \\
\hline $\begin{array}{l}\text { Valero: Diamond } \\
\text { Green Diesel }\end{array}$ & USA & Norco, LA & Tallow & HVO & UOP/ENI & Biodiesel & 500 & Small quantities? & 10 & & [8] \\
\hline \multicolumn{12}{|c|}{ FIRST COMMERCIAL } \\
\hline BSBios & $B R$ & $\begin{array}{l}\text { Passo Fundo, } \\
\text { Marialva }\end{array}$ & Bio oil & $\begin{array}{l}\text { HVO FAME } \\
\text { (fatty acid } \\
\text { methyl ether) }\end{array}$ & Petrobras & Biodiesel & $2 \times 230$ & & & & Author research \\
\hline Emerald Biofuels & USA & $\begin{array}{l}\text { Jennings, } \\
\text { Louisiana }\end{array}$ & $\begin{array}{c}\text { Non-edible } \\
\text { oils/fats }\end{array}$ & HVO & UOP/ENI & Biodiesel & 280 & & & Construction? & $\begin{array}{l}\text { https://emeraldonellc- } \\
\text { public.sharepoint.com/ }\end{array}$ \\
\hline Endicott Biofuels & USA & Port Arthur, TX & Bio oil & & & Biodiesel & 90 & & & Concept only? & Author research \\
\hline Hitachi Zosen & $\mathrm{J}$ & Kyoto & Bio oil & $\mathrm{HVO}$ & $\begin{array}{l}\text { Nippon Oil or } \\
\text { Hitachi Zosen }\end{array}$ & Biodiesel & 1 & No & 0.0 & Operating & $\begin{array}{l}\text { http://www.hitachizosen } \\
\text { co.jp/english/products/ } \\
\text { products010.html }\end{array}$ \\
\hline Pertamina & Indonesia & & Palm oil? & HVO? & & Biodiesel & 500 & & & & Author research \\
\hline Petrixo & UAE & Fujairah & Bio oil & $\mathrm{HVO}$ & UOP/ENI & Biodiesel & 400 & & & $\begin{array}{l}\text { Probably } \\
\text { cancelled }\end{array}$ & Author research \\
\hline Sinopec & PRC & Shanghai? & Bio oil & $\mathrm{HVO}$ & & Biodiesel & 20 & & & Planned? & \\
\hline Total & $\mathrm{F}$ & La Mède & Bio oil & $\mathrm{HVO}$ & Axens/IFP & Biodiesel & 650 & Planned & 30 & Construction & $\begin{array}{c}\text { https://www.axens.net/ } \\
\text { news-and-events/news/ } \\
369 / \text { axens-vegan\%C2\% } \\
\text { AE-technology-selected- } \\
\text { by-total-for-its-first- } \\
\text { biorefinery-in-france. } \\
\text { html\#.WoV-QudG2Uk }\end{array}$ \\
\hline
\end{tabular}


Table 2. Cont.

\begin{tabular}{|c|c|c|c|c|c|c|c|c|c|c|c|}
\hline Owner/Operator & Country & Location & Feedstock(s) & Process & $\begin{array}{l}\text { Process } \\
\text { Licensor }\end{array}$ & $\begin{array}{l}\text { Prime } \\
\text { Product }\end{array}$ & $\begin{array}{c}\text { Prime } \\
\text { Product } \\
\text { Capacity } \\
\text { kt/y } \\
\end{array}$ & $\begin{array}{l}\text { Is Biopropane } \\
\text { Extracted? }\end{array}$ & $\begin{array}{c}\text { Bioprop Capacity } \\
\text { kt/y (These Have } \\
\text { Been Etsimated from } \\
\text { Biodiesel Capacities.) } \\
\end{array}$ & Status 2018 & Source \\
\hline UPM & SF & Lappeenranta & Tall oil & $\mathrm{HVO}$ & UPM & Biodiesel & 100 & No & No, tall oil? & Operating & $\begin{array}{c}\text { www.biomassmagazine. } \\
\text { com/articles/15142/upm- } \\
\text { biofuels-enters-the- } \\
\text { bioplastics-market-with- } \\
\text { new-partners }\end{array}$ \\
\hline \multicolumn{12}{|c|}{ DEMONSTRATION } \\
\hline $\begin{array}{l}\text { Gas Technology } \\
\text { Institute }\end{array}$ & India & Bangalore & $\begin{array}{l}\text { Residues, wood, } \\
\text { stover, bagasse, } \\
\text { algae }\end{array}$ & $\begin{array}{l}\text { Hydrogenation, } \\
\text { fluid bed }\end{array}$ & $\begin{array}{c}\text { Gas } \\
\text { Technology } \\
\text { Institute }\end{array}$ & $\begin{array}{l}\text { Gasoline, } \\
\text { jet, diesel }\end{array}$ & & & & Commissioning & $\begin{array}{l}\text { https://www.cricatalyst. } \\
\text { com/cricatalyst/catalysts/ } \\
\text { renewables/integrated- } \\
\text { hydropyrolysis-and- } \\
\text { hydroconversion.html }\end{array}$ \\
\hline \multicolumn{12}{|c|}{ LABORATORY } \\
\hline La Laguna Univ & ES & & $\begin{array}{l}\text { UCO (used } \\
\text { cooking oil) and } \\
\text { atmospheric } \\
\text { gasoil }\end{array}$ & $\begin{array}{l}\text { Hydrogenation, } \\
\text { co-processing } \\
\text { with Atm gasoil }\end{array}$ & & Biodiesel & & & & & Author research \\
\hline $\begin{array}{l}\text { Mississippi, } \\
\text { University of }\end{array}$ & USA & & Oils, fats & & $\begin{array}{l}\text { Mississippi, } \\
\text { University of }\end{array}$ & Biopropane & & & & & Author research \\
\hline NIS & Serbia & Novi Sad & Bio oil & $\mathrm{HVO}$ & & Biodiesel & & & & Study & Author research \\
\hline ÖMV & A & & Bio oil & $\begin{array}{c}\text { Hydrogenation, } \\
\text { co-processing }\end{array}$ & & Biodiesel & & & & & Author research \\
\hline PKN Orlen & PL & & Bio oil & $\begin{array}{c}\text { Hydrogenation, } \\
\text { co-processing }\end{array}$ & & Biodiesel & & & & & Author research \\
\hline Sun Carbon & $\mathrm{s}$ & Tygelsjö & $\begin{array}{l}\text { Lignin, from } \\
\text { pulp mills }\end{array}$ & Lignin-to-biodiesel & SunCarbon & Biodiesel & & $\begin{array}{c}\begin{array}{c}\text { Small amounts } \\
\text { would be } \\
\text { produced }\end{array} \\
\end{array}$ & & Design & www.suncarbon.se \\
\hline Unipetrol & $\mathrm{CZ}$ & & $\begin{array}{l}\text { UCO (used } \\
\text { cooking oil) and } \\
\text { atmospheric } \\
\text { gasoil }\end{array}$ & $\begin{array}{c}\text { Hydrogenation, } \\
\text { co-processing } \\
\text { with Atm gasoil }\end{array}$ & & Biodiesel & & & & & Author research \\
\hline
\end{tabular}


Table 2. Cont.

\begin{tabular}{|c|c|c|c|c|c|c|c|c|c|c|c|}
\hline Owner/Operator & Country & Location & Feedstock(s) & Process & $\begin{array}{l}\text { Process } \\
\text { Licensor }\end{array}$ & $\begin{array}{l}\text { Prime } \\
\text { Product }\end{array}$ & $\begin{array}{l}\text { Prime } \\
\text { Product } \\
\text { Capacity } \\
\text { kt/y }\end{array}$ & $\begin{array}{l}\text { Is Biopropane } \\
\text { Extracted? }\end{array}$ & $\begin{array}{c}\text { Bioprop Capacity } \\
\text { kt/y (These Have } \\
\text { Been Estimated from } \\
\text { Biodiesel Capacities.) }\end{array}$ & Status 2018 & Source \\
\hline \multicolumn{12}{|c|}{ FOR LICENSE } \\
\hline Axens/IFP & $\mathrm{F}$ & & & $\mathrm{HVO}$ & Axens/IFP & Biodiesel & & & & & $\begin{array}{c}\text { https://www.axens.net/ } \\
\text { news-and-events/news/ } \\
369 / \text { axens-vegan\%C2\% } \\
\text { AE-technology-selected- } \\
\text { by-total-for-its-first- } \\
\text { biorefinery-in-france. } \\
\text { html\#.WsdiLZe-lPY }\end{array}$ \\
\hline Haldor-Topsoe & DK & & Bio oil & $\mathrm{HVO}$ & Haldor-Topsoe & Biodiesel & & & & & $\begin{array}{l}\text { https:///www.topsoe.com/ } \\
\text { sites/default/files/novel_ } \\
\text { hydrotreating_- } \\
\text { technology_for_ } \\
\text { production_of_green_- } \\
\text { diesel.ashx_ppdf }\end{array}$ \\
\hline $\begin{array}{l}\text { Hulteberg } \\
\text { CEngineering }\end{array}$ & $\mathrm{s}$ & & Bio oil & $\begin{array}{l}\text { Hydrogenation, } \\
\text { co-processing }\end{array}$ & & Biodiesel & & & & Design & $\begin{array}{l}\text { http://www.hulteberg. } \\
\text { com/newsletter4-its-all- } \\
\text { about-co-processing/ }\end{array}$ \\
\hline Syntroleum & USA & & Bio oil & HVO & Syntroleum & Biodiesel & & & & & Author research \\
\hline UOP/ENI & USA/I & & Bio oil & $\mathrm{HVO}$ & UOP/ENI & Biodiesel & & & & & $\begin{array}{l}\text { https://www.uop.com/ } \\
\text { hydroprocessing- } \\
\text { ecofining }\end{array}$ \\
\hline
\end{tabular}




\subsection{Dehydration}

Dehydration is a possible route to BioLPG. Minor quantities of BioLPG are being produced by 2-3 operators. Another operator is considering commercial-scale production. Two feedstocks come into primary consideration: bio-oil and glycerine.

Dehydration is also used to create longer-chain hydrocarbons from alcohols. So far, nobody appears to be working with propanol or butanol, but both are technically possible.

\subsubsection{Process Description}

Dehydration is the removal of water $\left(\mathrm{H}_{2} \mathrm{O}\right)$ from a larger molecule. The most common application is the conversion of alcohols to alkanes or alkenes. For instance, there is some commercial production of ethylene from ethanol, and styrene from benzyl alcohol.

\subsubsection{Technical Readiness}

As a chemical process, dehydration is mature and commercial. Process know-how has not focused on the production of BioLPG. Nonetheless, three processes are at a pilot-demonstration level for producing biopropane (Table 3).

Table 3. Dehydration projects that might produce BioLPG.

\begin{tabular}{|c|c|c|c|c|c|c|}
\hline $\begin{array}{l}\text { Owner/ } \\
\text { Operator }\end{array}$ & Location & Feedstock(s) & Process & Prime Product & Tech Readiness & Source \\
\hline $\begin{array}{l}\text { BioFuel } \\
\text { Solution }\end{array}$ & Limhamn, S & Glycerol & Dehydrogenation & Biopropane & Laboratory & $\begin{array}{l}\text { https: } \\
\text { //www.biofuel-solution.com/ }\end{array}$ \\
\hline Enysn & USA & Bio-oil? & $\begin{array}{l}\text { Fluid catalytic } \\
\text { cracking }\end{array}$ & Biodiesel & Unknown & Author research \\
\hline Petrobras & Sao Mateus do Sul, BR & $\begin{array}{c}\text { Petroleum gasoil } \\
80-90 \%+\text { bio-oil } \\
10-20 \%\end{array}$ & $\begin{array}{l}\text { Fluid catalytic } \\
\text { cracking }\end{array}$ & Biodiesel & Demonstration & $\begin{array}{l}\text { http://noticias.ambientebrasil. } \\
\text { com.br/clipping/2005/04/15/ } \\
\text { 18775-petrobras-pretende- } \\
\text { abrir-usina-de-biodiesel-em- } \\
\text { sao-mateus-do-sulpr.html }\end{array}$ \\
\hline $\begin{array}{l}\text { Renewable } \\
\text { Energy } \\
\text { Group }\end{array}$ & Geismar, LA, USA & Glycerin & Dehydrogenation & Biopropane & Concept & https://regi.com/ \\
\hline Tesoro & Martinez, CA, USA & Bio-oil & $\begin{array}{l}\text { Fluid catalytic } \\
\text { cracking }\end{array}$ & Biodiesel & Demonstration & Author research \\
\hline
\end{tabular}

Petrobras and Tesoro are reportedly feeding bio-oils to fluid catalytic crackers (FCCs) at conventional petroleum refineries, respectively in Brazil and the USA. Ensyn, a US-based company, is also reportedly testing cat-cracking of bio-oils, and is also reportedly working with Tesoro in California. FCCs are a significant source of $C_{3}$ and $C_{4}$ hydrocarbons in refineries, but these are mostly olefinic, i.e., propylene and butylenes. Some propane and butane are usually co-produced. The outputs of these FCCs are not clear.

Another potential dehydration route is dehydration of glycerol to biopropane. Glycerol is a logical feedstock candidate for propane, because they both have propyl structures. BioFuel Solution has published a detailed paper on its process [9] and in 2015 secured a European Patent EP 2358653 B1 (https://patents.google.com/patent/EP2358653B1/en) for it. The process involves several intermediate reactions between glycerol and propane.

At least one producer is considering converting glycerine to biopropane. Renewable Energy Group is investigating the production of some 65 kilotonnes/year of biopropane from about twice as much glycerine feedstock [10]. Renewable Energy appears to be considering a direct conversion of glycerine to propane: glycerine is reacted with hydrogen to yield propane and water. 


\subsubsection{Other Possible Dehydration Feedstocks}

There are other possibilities for dehydration to BioLPG—all of them remote from commercialisation.

(Bio) propanol and butanol could be dehydrated into propane and butane. As [11] reports, short chain alcohols (such as ethanol, methanol, n-butanol and isobutanol) can be catalytically converted to hydrocarbon fuels, but most of the work in this area is aimed at gasoline, diesel and jet fuel. The conversion of ethanol or butanol molecules typically involves a combination of dehydration (to ethene or butene), then oligomerisation reactions (combining molecules into longer-chains), followed by hydrogenation (adding hydrogen), isomerisation (branching to meet fuel specifications) and finally distillation into the required product streams.

There is no known production of biopropanol, but a joint-venture of oil-company BP and chemical company DuPont, called Butamax, has pursued development of biobutanol. The work has gone on for at least a decade, with plants announced but then not built. Its current commercial status is unclear. The target market for that biobutanol (should it ever be produced) is as a high-octane additive to gasoline.

Bio-methanol can be converted to propylene via the Lurgi process, and then further dehydrogenated to propane [7]. Bio-methanol can also be converted to gasoline, which generates BioLPG as a byproduct [11].

Bio-ethanol is the starting point of a Braskem process that can produce biopropane [7]. Sugarcanederived ethanol is dehydrated to ethylene: some is dimerized to butene and the rest undergoes metathesis with that ethylene to yield propylene. The propylene is finally dehydrogenated to propane. Braskem is known to operate the dehydration to ethylene, which is sold to make polyethylene. That bio-polyethylene is sold mainly for packaging of bio-cosmetics and so fetches a premium price. Although the conversion to propylene/propane is technically possible, Braskem says it is not pursuing other uses of the ethylene.

Several bioalcohol-to-hydrocarbon projects have been identified during this project (Table 4). This list is not exhaustive, and because none of them are believed to make BioLPG, it is not meant to be exhaustive. Nonetheless, it is one more possible route to BioLPG.

Table 4. Selection of alcohol-to-hydrocarbon projects.

\begin{tabular}{|c|c|c|c|c|c|}
\hline Owner/Operator & Country & Feedstock(s) & Prime Product & Tech Readiness & Source \\
\hline $\begin{array}{l}\text { Swedish Biofuels/KTH } \\
\text { Royal Institute of } \\
\text { Technology (Stockholm) }\end{array}$ & S & $\begin{array}{l}\text { Ethanol, } \\
\text { butanol }\end{array}$ & Jet fuel & Laboratory & Author research \\
\hline Swedish Biofuels & $S$ & Wood, wastes & Jet fuel & First commercial & Author research \\
\hline Byogy/Texas AM University & USA & Ethanol & Diesel & Unknown & Author research \\
\hline $\begin{array}{l}\text { Energy Biosciences } \\
\text { Institute/BP }\end{array}$ & USA & Corn (Maize) & Diesel & Unknown & https://energybiosciencesinstitute.org/ \\
\hline Gevo & USA & Corn (Maize) & Jet fuel & First commercial & $\begin{array}{l}\text { http://www.biomassmagazine.com/ } \\
\text { articles/15048/gevo-amends-isobutanol- } \\
\text { supply-agreement-with-musket?utm__ } \\
\text { source=Biomass\&utm_campaign= } \\
\text { 2fd66ac36c-EMAIL_CAMPAIGN_2018_ } \\
\text { 02_14\&utm_medium=email\&utm_ } \\
\text { term=0_53880fe73c-2fd66ac36c-94471541 }\end{array}$ \\
\hline Gevo & USA & Corn (Maize) & Jet fuel & Demonstration & $\begin{array}{l}\text { http://www.biomassmagazine.com/ } \\
\text { articles/15048/gevo-amends-isobutanol- } \\
\text { supply-agreement-with-musket?utm__ } \\
\text { source=Biomass\&utm_campaign= } \\
\text { 2fd66ac36c-EMAIL_CAMPAIGN_2018_ } \\
\text { 02_14\&utm_medium=email\&utm_ } \\
\text { term=0_53880fe73c-2fd66ac36c-94471541 }\end{array}$ \\
\hline $\begin{array}{l}\text { Pacific Northwest National } \\
\text { Laboratory/Imperium/Lanzatech }\end{array}$ & USA & Wood syngas & Jet fuel & Demonstration & $\begin{array}{l}\text { https://www.pnnl.gov/news/release. } \\
\text { aspx?id=4527 }\end{array}$ \\
\hline Sundrop Fuels/ExxonMobil & USA & $\begin{array}{l}\text { Wood syngas } \\
+ \text { nat gas } \mathrm{H} 2\end{array}$ & Gasoline & First commercial & $\begin{array}{l}\text { https://www.businesswire.com/news/ } \\
\text { home/20120627006303/en/Sundrop- } \\
\text { Fuels-ExxonMobil-MTG-Technology- } \\
\text { Nation\%E2\%80\%99s-\%E2\%80\%9CGreen }\end{array}$ \\
\hline Swedish Biofuels/Lanzatech & USA & $\begin{array}{l}\text { Syngas, } \\
\text { steel mill }\end{array}$ & Jet fuel & Demonstration & $\begin{array}{l}\text { http://www.lanzatech.com/world-first- } \\
\text { low-carbon-fuel-to-be-developed-for- } \\
\text { virgin-atlantic/ }\end{array}$ \\
\hline
\end{tabular}




\section{Biological Processes and Projects}

The three biological processes that can lead to BioLPG are fermentation, hydrolysis fermentation, and digestion. All are well-known, and both fermentation and digestion are commercially well-established, albeit not for BioLPG. Hydrolysis fermentation is in initial stages of commercialisation, also not for BioLPG.

Fermentation generates a small amount of BioLPG (biobutylene), and commercial-scale production is planned. Fermentation of biopropane has been proven at laboratory scale. Hydrolysis fermentation has produced BioLPG at a laboratory scale. Digestion is being tried by one demonstration project.

\subsection{Fermentation}

Fermentation is the conversion of sugars by bacteria, yeasts or other microorganisms, in the presence of air (aerobic), into other products. The best-known example is the fermentation of alcoholic beverages: yeast convert sugars into ethanol. Alcohol is fermentation's best-known product, but fermentation can generate other products, including BioLPG (Table 5).

Biobutylene is only BioLPG produced by fermentation: this has so far been done only at a demonstration scale. Global Bioenergies converts sucrose (sugar) from sugar beets and sugarcane to isobutylene at a demonstration plant in Leuna, Germany. Capacity is reported at around 150 tonnes/year. Plans are underway to build a commercial-scale plant somewhere in France, reportedly of 50-kilotonne/year size.

Global Bioenergies has its own process, IBN-One process, that uses genetically engineered microorganisms to convert sugar to propylene, butylenes, propanols, and butanols. By tweaking the process, it can be directed to one or more of those possible products. Most fermentation processes require significant amounts of energy to separate the product from the fermentation broth (e.g., distillation of the alcohol from the mash). However, with IBN-One propylene and butylenes are emitted as gases, which avoids the need for distillation [12].

Table 5. Fermentation projects relevant to BioLPG.

\begin{tabular}{cccccc}
\hline Owner/Operator & Location(s) & Feedstock(s) & Prime Product & Tech Readiness & Source \\
\hline C3 BioTechnologies & $\begin{array}{c}\text { Manchester, } \\
\text { UK }\end{array}$ & Glucose & Unknown & Unknown & $\begin{array}{l}\text { https://www.manchester.ac.uk/ } \\
\text { research/beacons/breakthroughs/ } \\
\text { synthetic-bio-propane/ }\end{array}$ \\
\hline Global Bioenergies & Leuna, D & $\begin{array}{c}\text { Sugarcane, sugar } \\
\text { beet, (LC sugars) }\end{array}$ & Isobutene (gas) & Demonstration & $\begin{array}{l}\text { http://www.global-bioenergies. } \\
\text { com/global-bioenergies-adapts- } \\
\text { its-bio-isobutene-process-to- } \\
\text { sucrose/?lang=en }\end{array}$ \\
$\begin{array}{c}\text { Global Bioenergies Cristal } \\
\text { Union: IBN-One }\end{array}$ & $\begin{array}{c}\text { France, in } \\
\text { planning }\end{array}$ & $\begin{array}{c}\text { Sugar beet } \\
\text { co-products }\end{array}$ & Isobutene & Commercial & $\begin{array}{l}\text { http://www.global-bioenergies. } \\
\text { com/global-bioenergies-adapts- } \\
\text { its-bio-isobutene-process-to- } \\
\text { sucrose/?lang=en }\end{array}$ \\
\hline $\begin{array}{c}\text { University of Turku, } \\
\text { Imperial College London }\end{array}$ & $\begin{array}{c}\text { Turku, SF } \\
\text { London, UK }\end{array}$ & $\begin{array}{c}\text { Glucose, } \\
\text { butyraldehyde }\end{array}$ & Biopropane & Laboratory & [13] \\
\hline
\end{tabular}

Fermentation of biopropane has been proven at laboratory scale. A team from Finland's University of Turku and England's Imperial College London have published two papers detailing the experiments $[13,14]$ that involve the microorganisms cyanobacteria and E. coli. It is not known that there are any plans to scale up beyond the laboratory.

Converting sugars to chemicals is an active area of development by 'bioproduct' companies, including venerable names like DSM, DuPont, and Total as well as newcomers such as Amyris, Myriant, GEVO, and of course Global Bioenergies. Except for Global Bioenergies's isobutylene, none of the target products are fuels, they are chemical intermediates such as acrylic acid, adipic acid, farnesene, polylactic acid, and succinic acid.

Sugars can of course be fermented to alcohols that in turn can be converted to BioLPG. National Renewable Energy Laboratory [7] reports a possible route from sugars to propanol or propionic acid as intermediates, with subsequent catalytic dehydration to propylene followed by catalytic hydrogenation of propylene to propane. 
A final pathway similar to fermentation is the conversion of butyric acid to biopropane. As [7] reports, genetically engineered microbes can do the reaction of (butyric acid) $\mathrm{C}_{4} \mathrm{H}_{7} \mathrm{COOH} \rightarrow \mathrm{C}_{3} \mathrm{H}_{8}+$ $\mathrm{CO}_{2}$. Most butyric acid today is produced synthetically from fossil feedstocks, but it can be made from bio feedstocks as well.

\subsection{Hydrolysis and Fermentation of Cellulose}

Cellulose is generally believed to be the most abundant bio-material on earth. It is the structural material of most plants. Its chemical structure is a polysaccharide, i.e., a polymer of sugar molecules. Cellulose is made only of glucose $\left(\mathrm{C}_{6}\right)$, while the less-abundant hemi-cellulose is polymerised from a variety of sugars. The sugar in cellulose cannot be fermented conventionally, because microorganisms are not capable of breaking down the polymer into its constituent sugars. Starch is also a polysaccharide, but its polymer can be broken down into sugars relatively easily.

Hydrolysis is a process to break down cellulose (or hemi-cellulose) into its sugars. These then can be fermented into other products, as reviewed above.

There are two general approaches to hydrolysis: treating the cellulose with steam and acid to break it down or treating the cellulose with special enzymes that also can break it down. Much research and development has gone into this over the past 40 years, precisely because cellulose is so abundant and could supply large proportions of fuels and chemicals. Even so, the process has only reached the technological readiness of 'first commercial', and even that is tenuous.

Most of the development has been driven by the aim to make cellulosic ethanol, by hydrolysis to sugar and then fermentation. Common feedstocks for this are straw and stover (the stalk and leaves of a corn/maize plant). Wood is also possible, but less suitable, because it requires more up-front processing to chop it up. The first commercial scale plants to do this, one owned by Abengoa and the other a joint venture of companies DSM and POET, opened in the USA in 2014. Abengoa subsequently went bankrupt-which is symptomatic of the industry: the economics are not self-sustaining; subsidies are required.

Sugars produced from hydrolysis can in principle be fermented similarly to 'natural' sugars. Indeed, Global Bioenergies reports that its IBN-One process to convert sugar to BioLPG has been successfully tested on cellulosic-derived sugar at a laboratory scale [12]

\subsection{Digestion of Organic Wastes}

Organic wastes with high water content-such as manure, sewage sludge, or food remnantssometimes are treated by digestion, i.e., anaerobic fermentation. The output is biogas, typically around $50 \%$ methane, most of the rest carbon dioxide with small amounts of organic acids, nitrogenous and sometimes sulphurous compounds as well. Biogas is also produced 'naturally' at waste landfills, from the digestion of waste organics that can be either bio or fossil in origin.

Biogas is used as energy in two main ways. One is to combust it onsite in an internal-combustion engine that runs an electric generator. This has been done with landfill-biogas for decades now. The other is to clean and upgrade it to biomethane ( $90 \%$ purity) and inject that into the natural gas grid. This has become a significant industry in the past $10-15$ years.

A third way is also possible: the digestion-gas could be synthesised into higher hydrocarbons. Two companies have worked on this process, both at laboratory scale.

\subsubsection{Biomethane to Propane, Alkcon}

In 2016 A US-based company, Alkcon Corporation, announced a process for converting methane, purified from digested biogas, to propane (Figure 4). No details are available. According to [7], presumably this is a thermochemical route which involves conversion of methane to ethane (first reactor) with subsequent conversion of ethane plus methane to propane (second reactor). Hydrogen is produced as a by-product. 


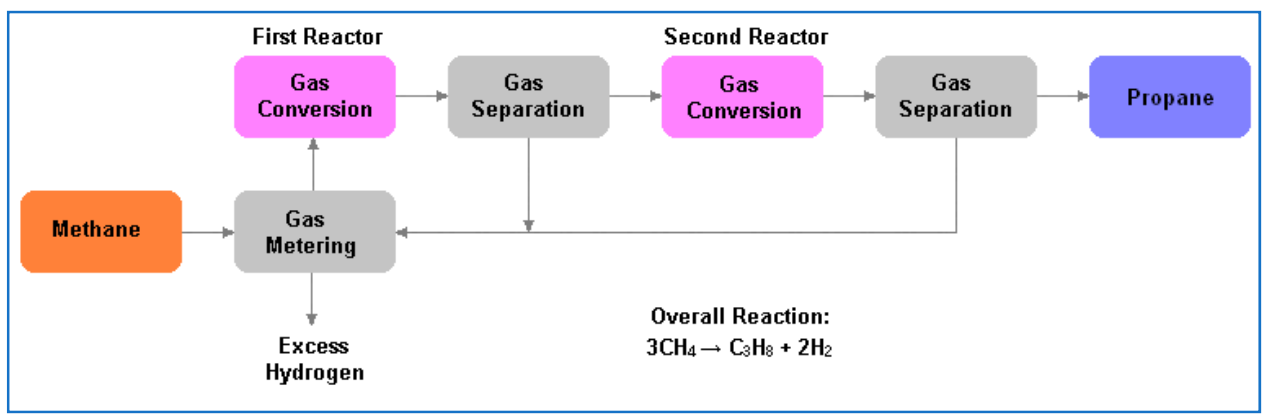

Figure 4. Alkcon's process for methane to propane.

\subsubsection{Bio- $\mathrm{CO}_{2}$ to Propane and Methane, 'FutureLPG'}

A German consortium led by the Technical University of Clausthal plans to test a digestion-based process at laboratory scale for 30 months, starting in 2019. Unlike the Alkcon process that uses methane from biogas as feedstock, the FutureLPG process uses carbon dioxide produced in digestion. This will be reacted with hydrogen (produced by electrolysis of water, using low-carbon power) in a Fischer-Tropsch synthesis to produce biomethane and BioLPG (the mix of propane/butane is not clear).

This approach shares some aspects in common with those using atmospheric carbon dioxide as feedstock (see Section 5).

\section{Advanced Chemical Processes and Projects}

There are two advanced chemical process types that can lead to BioLPG: gaseous conversion and synthesis, and liquid conversion and synthesis. They are advanced, because they are technically challenging and not well-established commercially. The feedstocks for these are cellulosics and wastes.

Neither of these process types currently deliver commercial quantities of BioLPG. Still they are interesting, because they offer the possibility of using cellulosic- and waste-feedstocks at a large scale, and so potentially could produce significant volumes of BioLPG.

\subsection{Process Descriptions}

All these processes break down the large, complex molecules of biomass into smaller, simpler ones. These smaller, simpler molecules are then synthesised/refined into fuels. There are two main steps: gaseous or liquid conversion, followed by synthesis. The most promising route to BioLPG is gasification and synthesis, because the other routes usually are directed at longer-chain or more-complex hydrocarbons (Figure 5).

\section{Feedstock}

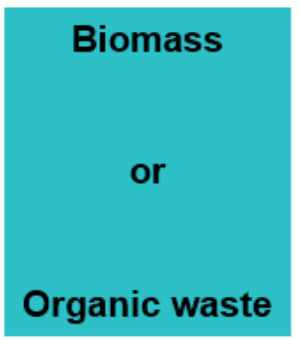

\section{Intermediate}

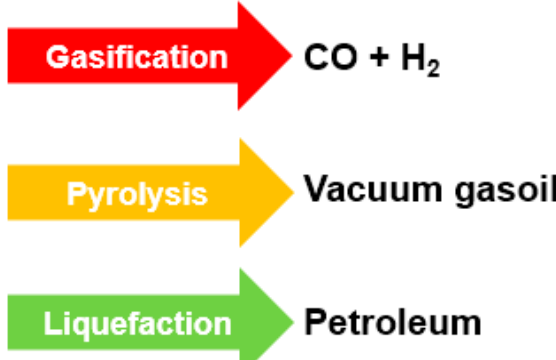

\section{Potential BioLPG yield}

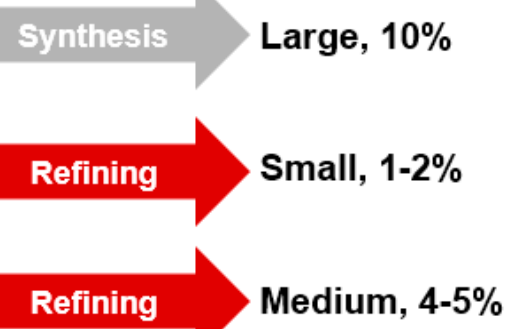

Figure 5. Advanced chemical paths to BioLPG.

\subsubsection{Gaseous Conversion}

Gaseous conversion (of biomass) can be done in two main ways: gasification and pyrolysis. Gasification is done at severe temperatures and pressures, in the presence of air and/or steam, 
while pyrolysis is more moderate and without air or steam. Gasification blasts the feedstocks into syngas, a gaseous mixture of small molecules, mostly carbon monoxide and hydrogen. Pyrolysis 'cooks' the feedstock into an oil.

\section{Gasification}

A gasifier hits its hydrocarbon feedstock with high temperatures $(700+C)$ and pressures $(5-10$ bar) plus air or oxygen and often steam as well. The harsh conditions blast apart long molecules into a mix of short ones, called syngas, composed mainly of carbon monoxide and hydrogen, but there usually is also some carbon dioxide, some methane and small amounts of other compounds. The precise mix of these depends on the gasification conditions and on the composition of the feedstock. Natural gas (methane, $\mathrm{CH}_{4}$ ) delivers a hydrogen-rich syngas, whereas coal (say, $\mathrm{C}_{240} \mathrm{H}_{90} \mathrm{O}_{4} \mathrm{NS}$ for anthracite) delivers a more carbon-rich syngas. Biomass (mostly cellulose, $\mathrm{C}_{6} \mathrm{H}_{10} \mathrm{O}_{5}$ ) delivers a more oxygen-rich syngas.

Pyrolysis

A pyrolyser hits its hydrocarbon feedstock with moderate temperatures $\left(300-600{ }^{\circ} \mathrm{C}\right)$ and limited oxygen or air, usually at ambient pressure. The hydrocarbons react with each other, forming a combination of oils, gases and solids (char). The precise mix of these depends on the pyrolysis conditions and on the composition of the feedstock. Unlike gasification, pyrolysis mostly generates mid-sized molecules, say $\mathrm{C}_{5}$ to $\mathrm{C}_{20}$, and these are mostly still hydrocarbons. When biomass is pyrolyzed, because it contains significant oxygen, oxygenates are produced such as carboxylic acids, phenols, sugars, and water.

A well-known application of pyrolysis is the conversion of wood to charcoal. The product here is the char, while the gases and oils are vented. Of more interest in this study is pyrolysis that leads mainly to pyrolysis oil, sometimes called bio-oil—which is broadly similar in composition to vacuum gasoil.

\subsubsection{Liquid Conversion}

A liquefaction process hits a wet hydrocarbon feedstock with moderate temperatures (up to $400^{\circ} \mathrm{C}$ ) and high pressures. Sometimes the conditions are enough to make the water go supercritical. As in pyrolysis, the hydrocarbons react with each other, and with the water, but the product is mainly an oil, also sometimes called bio-oil—which is broadly similar to petroleum [15], except with higher oxygen content.

\subsubsection{Synthesis}

Synthesis takes the smaller, simpler molecules created by gaseous or liquid conversion, and converts them into fuels.

Syngas from gasification is mainly carbon monoxide and hydrogen. It must be cleaned of tars and other contaminants, and carbon dioxide is also removed. The $\mathrm{CO}$ (carbon monoxide) and hydrogen are then catalytically reacted to make longer-chain hydrocarbons. The precise mix depends on conditions and on the syngas composition, but typically it covers about the same range as that of a petroleum refinery. Of course, this is by design. In fact, the target range can be adjusted towards most of the longer-chain or shorter-chain hydrocarbons, including those for BioLPG.

Pyrolysis oil is similar to vacuum gasoil (VGO), a common refinery intermediate, except that when made from biomass, it has more oxygen. The py-oil can be processed (synthesised) similarly to VGO in a conventional refinery, even directly blended with fossil VGO at $10-20 \%$. It can be cat cracked, or hydro-deoxygenated and then hydrocracked.

\subsection{Technical Readiness (with Biomass/Waste Feedstock)}

For biomass or organic wastes, none of the advanced chemical processes have gone commercial (Table 6). This is mainly due to their economic unattractiveness, but technical challenges can also be 
considerable. For the first two, however, there is considerable know-how that has been built up in their application to fossil hydrocarbons, especially for gasification and synthesis.

Table 6. Technical readiness of advanced chemical processes.

\begin{tabular}{ccc}
\hline Process Type & Fossil Feedstocks & Biomass Feedstocks \\
\hline Gasification and synthesis & Commercial & Demonstration \\
Pyrolysis and synthesis & Demonstration & Demonstration \\
Liquefaction and synthesis & Not known & Demonstration \\
\hline
\end{tabular}

Gasification and synthesis is used commercially for fossil feedstocks. Probably the best-known examples are the coal-to-liquids (fuel) plants operated by Sasol in South Africa. Another well-known example is the Great Plains Synfuels Plant in American North Dakota, opened in 1986, that converts coal to fuel gas. These processes have never caught on widely, because the economics are unattractive. South Africa, and in earlier times Germany, turned to coal-to-liquids for political reasons, i.e., they had limited access to crude oil. Other prominent examples of gasification and synthesis are natural gas-to-liquids plants in Malaysia and Qatar, and methanol-to-gasoline in China and New Zealand.

Pyrolysis and synthesis has for years been proposed for the treatment of disused tyres, which can be a disposal problem and a fire hazard. The barrier to their commercialisation has been more economic than technical.

\subsection{Process Developers/Licensors}

For gaseous conversion and synthesis from biomass or waste that could potentially lead to BioLPG, several developers and licensors are active (Table 7). So too, in liquid conversion and synthesis (Table 8).

Table 7. Developers/licensors of relevant gaseous conversion and synthesis processes.

\begin{tabular}{|c|c|c|c|}
\hline Process & Process Name & Developer/Licensor & Source \\
\hline $\begin{array}{l}\text { Gasification + } \\
\text { Fischer-Tropsch }\end{array}$ & Biomass to liquids & Choren & $\begin{array}{l}\text { www.ieatask33.org/app/webroot/files/file/2014/ } \\
\text { WS2/Kittelmann.pdf }\end{array}$ \\
\hline $\begin{array}{c}\text { Gasification + } \\
\text { Fischer-Tropsch }\end{array}$ & Biomass to LPG & Japan Gas Synthesis & [16] \\
\hline $\begin{array}{l}\text { Gasification }+ \\
\text { Fischer-Tropsch }\end{array}$ & & Maverick Synfuels & Author research \\
\hline $\begin{array}{l}\text { Gasification + } \\
\text { Fischer-Tropsch }\end{array}$ & & Shell & Author research \\
\hline $\begin{array}{l}\text { Gasification + } \\
\text { Fischer-Tropsch }\end{array}$ & & Velocys & https://www.velocys.com/ \\
\hline $\begin{array}{l}\text { Gasification and } \\
\text { pyrolysis }\end{array}$ & MILENA & $\begin{array}{c}\text { Energy Research Centre } \\
\text { of the Netherlands and } \\
\text { Royal Dahlman }\end{array}$ & $\begin{array}{l}\text { ftp://ftp.ecn.nl/pub/www/library/report/2016/ } \\
\text { m16032.pdf }\end{array}$ \\
\hline Gasification-to-power & & Energos & www.energos.com \\
\hline Gasification-to-power & & Outotec & https://www.outotec.com/ \\
\hline Gasification-to-power & & Syngas Products & Author research \\
\hline Methanol-to-gasoline/LPG & TIGAS & Haldor-Topsoe & $\begin{array}{l}\text { https://www.topsoe.com/processes/gasoline- } \\
\text { synthesis/tigastm }\end{array}$ \\
\hline Methanol-to-propylene & & Lurgi & Author research \\
\hline Pyrolysis & RTP & Enysn & www.ensyn.com/rtp-applications \\
\hline $\begin{array}{l}\text { Pyrolysis } \\
\text { (hydropyrolysis) }\end{array}$ & $\mathrm{IH} 2$ & Gas Technology Institute & $\begin{array}{l}\text { https://www.cricatalyst.com/cricatalyst/ } \\
\text { catalysts/renewables/integrated-hydropyrolysis- } \\
\text { and-hydroconversion.html }\end{array}$ \\
\hline Pyrolysis & $\begin{array}{l}\text { Biomass catalytic } \\
\text { cracking }\end{array}$ & $\begin{array}{l}\text { KiOR (since renamed to } \\
\text { Inaeris Technologies) }\end{array}$ & Author research \\
\hline Synthetic natural gas & & $\begin{array}{c}\text { Energy Research Centre } \\
\text { of the Netherlands }\end{array}$ & $\begin{array}{l}\text { ftp://ftp.ecn.nl/pub/www/library/report/2016/ } \\
\text { m16032.pdf }\end{array}$ \\
\hline Synthetic natural gas & & Göbigas & https://sv.wikipedia.org/wiki/GoBiGas \\
\hline
\end{tabular}


Table 8. Developers/licensors of relevant liquid conversion and synthesis processes.

\begin{tabular}{lc}
\hline \multicolumn{1}{c}{ Developer/Licensor } & Process Name \\
\hline Biochemtex/ETH Zürich/KLM (Dutch national airline)/RE-CORD (consortium of Italian universities) & \\
Chalmers University & Cat-HTR \\
Licella & \\
Muradel & \\
Next Fuels & \\
Shell HTU & Hydrofaction \\
Southern Oil Refining & \\
Steeper Energy/Aalborg University & \\
Altaca/SCF Technologies & \\
Chemtex & \\
Genifuel/Pacific Northwest National Laboratory & \\
Research Triangle Institute & Bioforming \\
\hline Virent &
\end{tabular}

Source: Author research.

\subsection{Projects and Production}

These are divided into three groups.

For gaseous conversion and synthesis of cellulosics, about 50 projects have been identified (see Section 4.4.1), divided into five classes. For gaseous conversion and synthesis of mixed waste, a list has not been compiled, because this is not yet a clear route to BioLPG. Nonetheless, the concept is presented in the second subsection below.

Cellulosics and mixed waste are separated, because process developers tend to view them separately. There are two main reasons for this:

- Cellulosics—say, wood chips or straw or forest residues-can be relatively homogeneous, regardless of whether they are products or wastes. A process can be adjusted carefully to specific feedstocks. Mixed wastes, on the other hand, by definition are of varying composition. Trying to convert them into intermediates that can be further converted into products is technically challenging. Several plants have been built but later shut down because of fouling in their processes (see Section 5).

- The other big differences between cellulosics and mixed waste are availability and economics (revenues). Availability of mixed waste is good, and logistics already exist: it is collected, it must go somewhere. By contrast, logistics and collection of cellulosics are thin on the ground. Most cellulosics are not collected centrally, and initiating collection would incur investment and operating costs. As for economics: because mixed waste usually comes with a 'gate fee', i.e., a payment to dispose of it, there is a ready revenue stream to help finance (say, a gaseous conversion and synthesis plant to do that). Cellulosics generally do not have an attendant 'gate fee'. This could be created, just as they have been for some recyclables and wastes (used cooking oil, for example), but again, it would incur investment and changes in operating practice.

For liquid conversion and synthesis of biomass, about 14 projects have been identified (see Section 4.4.3).

\subsubsection{Gaseous Conversion and Synthesis, Cellulosics}

Five processes are of interest. The first four are gasification and synthesis: gasification and Fischer-Tropsch; gasification-to-methanol; methanol-to-gasoline/LPG; and synthetic natural gas. The final one is pyrolysis and synthesis. These are covered below. Four of these processes can potentially generate significant yields of BioLPG (Table 9). 
Table 9. Potential (maximum) yield of BioLPG as a fraction of total output by weight.

\begin{tabular}{ccc}
\hline Process General Description & Potential BioLPG Yield & Specific Process \\
\hline Fischer-Tropsch & $7.5 \%$ & Larson theoretical design \\
Fischer-Tropsch & $50 \%$ & Japan Gas Synthesis \\
Methanol-to-gasoline/LPG & $8.4 \%$ & 'Green Gasoline' \\
Fast hydropyrolysis & $10 \%$ & IH2 process \\
\hline
\end{tabular}

Syngas Synthesis

Syngas from a gasifier can be further processed in a lot of directions (Figure 6). This report aims to cover only those relevant to BioLPG: Fischer-Tropsch, syngas-to-methanol-to-gasoline (and LPG); repurposed methanol; and synthetic natural gas.

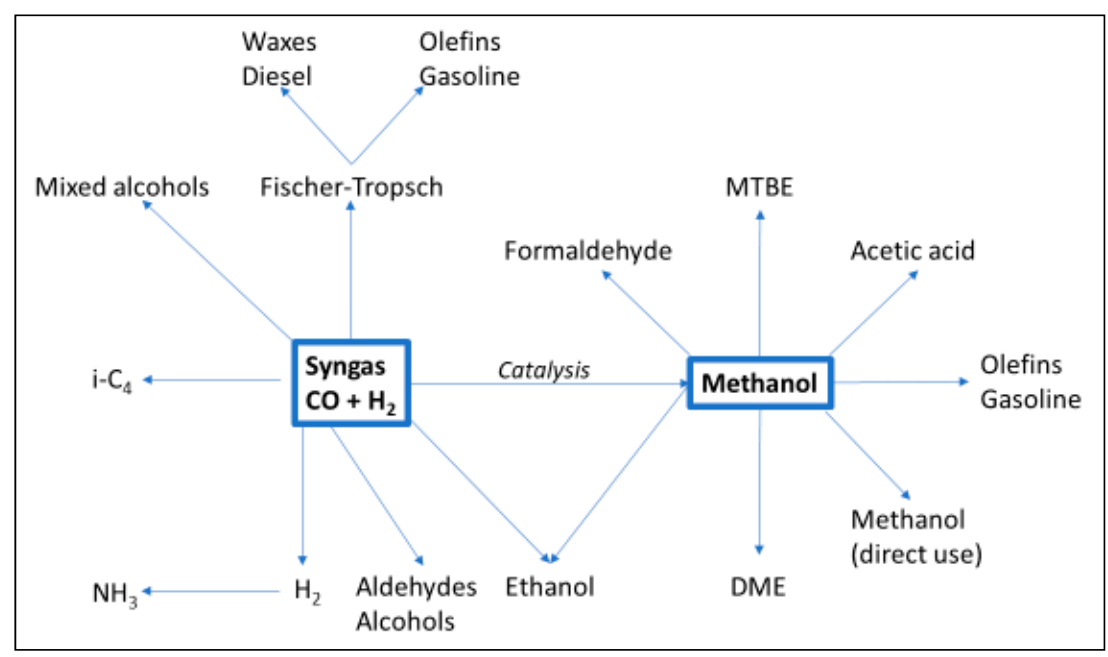

Figure 6. Processing options for syngas. Source: [17].

Fischer-Tropsch

One option for syngas is to synthesise it into liquid fuels with the Fischer-Tropsch (FT) process. About 25 projects have been identified (Table 10) that use FT process to do this, starting from cellulosic feedstocks. None of those actually operating are believed to be commercial, although some commercial projects reportedly are in the works.

Do they or will they produce BioLPG? Probably very little, if at all. These projects are targeted at mainstream refined products: gasoline, diesel and jet fuel. This report estimates the BioLPG output at $2-3 \%$ by weight. Or it could be less: FT processes are often designed to use most or all their LPG output as process fuel.

Could they produce BioLPG? Yes. A published model of a biomass FT plant [18] yields about $7.5 \%$ by energy content of LPG. About $5 \%$ is butane, $2.5 \%$ propane. In the same design, much of the butane is cannibalised in the process, but one of the authors, Larson, has said that this butane could be replaced by other process fuels.

Moreover, FT plants can produce LPG when they run on fossil feedstocks. At Sasol's coal-to-liquids plant in South Africa, total LPG yield is around 5\% (some is cannibalised, actual LPG production is lower). In a design study for the US Department of Energy, [19] engineered nine different configurations of FT with coal as feedstock. Propane/butane yields ranged from $3.5-6.5 \%$ by weight of all outputs. About two-thirds of that output was butane, one-third propane. Lab-scale research at Canada's University of Saskatchewan (https://doi.org/10.1002/cjce.5450810208) has used fossil syngas feedstocks to achieve $C_{3} / C_{4}$ yields of nearly one-third of the output. 
Table 10. Gaseous conversion and synthesis projects for BioLPG, by process.

\begin{tabular}{|c|c|c|c|c|c|c|}
\hline Owner/Operator & Country & Location & Feedstock & Prime Product & $\begin{array}{l}\text { Prime Product } \\
\text { Capacity kt/y }\end{array}$ & Source/Note \\
\hline \multicolumn{7}{|c|}{ Gasification + Fischer-Tropsch } \\
\hline BIOENERGY 2020+ & A & & Wood & FT liquids & 0.04 & Author research \\
\hline BioTfuel-Uhde & $\mathrm{F}$ & & Torrefied wood & FT diesel, jet & 0.064 & Author research \\
\hline Choren Industries & $\mathrm{D}$ & Freiberg (Sachsen) & Wood & & 13 & Closed \\
\hline Cutec & D & & $\begin{array}{l}\text { Straw, wood, dried silage, } \\
\text { organic residues }\end{array}$ & FT liquids & 0 & Author research \\
\hline ENVIA Energy & USA & Natchez, Miss & Woody biomass & Diesel, naphtha, wax & 61 & Planned \\
\hline ENVIA Energy & USA & Oklahoma City, OK & Landfill gas and natural gas & Diesel, naphtha, wax & 0 & Author research \\
\hline Flambeau River BioFuels & USA & Wisconsin Rapids, WI & Black/brown liquor & & & Author research \\
\hline Frontline Bioenergy & USA & & Wood, sorted municipal waste & FT jet & 0.04 & Author research \\
\hline Fulcrum Biofuels & USA & & Municipal waste, prepared & FT diesel, jet & 30 & Author research \\
\hline $\begin{array}{c}\text { Gridley Biofuels Project/Red } \\
\text { Lion/Greyrock }\end{array}$ & USA & & Agricultural residues & FT diesel & 0.368 & Author research \\
\hline Haldor Topsoe Gas Technology Institute & USA & & Wood pellets & FT gasoline & 1.04 & Author research \\
\hline $\begin{array}{l}\text { Japan Synthesis Gas, Kutakyushu } \\
\text { University }\end{array}$ & $\mathrm{J}$ & & Wood & & & Author research \\
\hline Joule Unlimited/Red Rock Biofuels & USA & & Wood wastes residues & FT diesel, jet & 44 & Planned \\
\hline Kaidi & PRC & & Biogenic waste & FT diesel & 0.416 & Author research \\
\hline Kaidi & $\mathrm{SF}$ & & Forest residues & FT diesel, jet & 200 & Planned \\
\hline Maverick Synfuels & USA & Chapel Hill, NC & Biomass & & & Author research \\
\hline NewPage Corporation & USA & & & & & Author research \\
\hline NREL & USA & & Lignocellulosics & FT liquids & 0.048 & Author research \\
\hline Saskatchewan University & CAN & & Syngas & $\mathrm{C}_{2}-\mathrm{C}_{4}$ olefins & & Author research \\
\hline Shell & USA & Houston & Hydrocarbons & & & Author research \\
\hline Southern Research Institute/TRI & USA & & Wood waste forest residues & $\begin{array}{c}\text { FT liquids, mixed alcohols, } \\
\text { industrial sugars }\end{array}$ & 0 & Author research \\
\hline TRI & USA & & Wood waste forest residues & FT liquids & 0.016 & Author research \\
\hline Tübitak MRC-Energy Institute & $\mathrm{T}$ & & $\begin{array}{l}\text { Hazelnut shell, olive cake, } \\
\text { wood chip lignite }\end{array}$ & FT liquids & 0.256 & Author research \\
\hline Velocys & A & & Wood & FT diesel & 0.024 & Author research \\
\hline \multicolumn{7}{|c|}{ Gasification-to-methanol } \\
\hline Bio-MCN & $\mathrm{NL}$ & Groningen & Glycerol & Methanol & & Operating \\
\hline
\end{tabular}


Table 10. Cont.

\begin{tabular}{|c|c|c|c|c|c|c|}
\hline Owner/Operator & Country & Location & Feedstock & Prime Product & $\begin{array}{c}\text { Prime Product } \\
\text { Capacity kt/y }\end{array}$ & Source/Note \\
\hline \multicolumn{7}{|l|}{ Methanol-to-gasoline/LPG } \\
\hline ExxonMobil & USA & & Could run on biomass & Methanol and LPG & & $\begin{array}{l}\text { Has operated on coal and } \\
\text { gas, but not bio feedstocks }\end{array}$ \\
\hline Haldor-Topsoe & DK & & Wood & Methanol and LPG & & $\begin{array}{l}\text { Demonstration in USA } \\
\text { Green Gasoline }\end{array}$ \\
\hline \multicolumn{7}{|c|}{ Synthetic natural gas } \\
\hline $\begin{array}{l}\text { Energy research Centre of the } \\
\text { Netherlands }\end{array}$ & NL & & Biomass & Synthetic natural gas & & Demonstration \\
\hline Engie & $\mathrm{F}$ & & Wood, straw & Synthetic natural gas & & Demonstration? \\
\hline Göbigas & $\mathrm{s}$ & Gothenburg & Wood residues & Synthetic natural gas & & Demo plant, now closed. \\
\hline \multicolumn{7}{|c|}{ Pyrolysis } \\
\hline Bioliq/Karlsruhe Institute of Technology & $\mathrm{D}$ & & Wood, waste wood, straws, hay & $\begin{array}{l}\text { Pyrolysis oil, DME, } \\
\text { gasoline }\end{array}$ & 1.44 & Author research \\
\hline BTG Bioliquids & NL & Hengelo & Wood biomass and/or residues & Pyrolysis oil & 12 & $\begin{array}{l}\text { Subsidised by EU Research } \\
\text { funding }\end{array}$ \\
\hline Cool Planet & USA & & Wood residues thinnings & Pyrolysis oil, Gasoline? & 30 & $\begin{array}{l}\text { Said to be under } \\
\text { construction }\end{array}$ \\
\hline CRI (subsidiary of Shell) & USA & & Straw, wood residues, wastes & Gasoline, jet, diesel & 1.68 & Author research \\
\hline Ensyn & BR & & Biomass and/or waste & & & Author research \\
\hline Ensyn & CAN & Renfrew, ON & Lignocellulosics & Pyrolysis oil & 9 & Author research \\
\hline Ensyn & Malaysia & & Lignocellulosics & & & Author research \\
\hline $\begin{array}{l}\text { Envergent/Ensyn/UOP (engineering } \\
\text { contractor) }\end{array}$ & CAN & & Forest residues straw & Pyrolysis oil & 320 & Under construction? \\
\hline Enysn & CAN & & Biomass and/or waste & & & Author research \\
\hline Fortum/Valmet/PREEM (refiner) & SF & Joensuu & Woodchips and thinnings & Pyrolysis oil & Commercial scale & Planned for 2020 \\
\hline $\begin{array}{l}\text { Iowa /National Renewable Energy } \\
\text { Laboratory/ConocoPhilips }\end{array}$ & USA & & Biomass & Gasoline, diesel, jet & 3.2 & Author research \\
\hline KiOR (now called Inaeris Technologies) & USA & & Biomass & & & Author research \\
\hline $\begin{array}{l}\text { LignoCat/VTT Technical Research } \\
\text { Centre/Fortum/UPM/Valmet }\end{array}$ & $\mathrm{SF}$ & & Biomass & Upgraded pyrolysis oil & Not yet public & Author research \\
\hline Next BTL/Future Blends & GB & & Lignocellulosics & Pyrolysis oil & 0.024 & Author research \\
\hline Petrobras/BTG & BR & & Biomass & Gasoline, diesel, jet & 1.36 & Author research \\
\hline Petrobras/Ensyn/NREL & $B R$ & & Biomass & Gasoline, diesel, jet & 1.76 & Author research \\
\hline Research Triangle Institute & USA & & Lignocellulosics & Bio-crude & 0.024 & Author research \\
\hline SynSel Energy/CRI Criterion Catalyst & $\mathrm{N}$ & Grenland & Forest residues & Gasoline jet, diesel, & 1.68 & Author research \\
\hline UOP & USA & Oahu, Hawaii & Biomass & Gasoline, diesel, jet & 0.16 & Author research \\
\hline Gas Technology Institute/Shell & USA & Chicago, Ill & $\begin{array}{l}\text { Residues, wood, stover, } \\
\text { bagasse, algae }\end{array}$ & Gasoline, jet, diesel & 0.008 & $\begin{array}{l}\text { Piloted in Chicago and } \\
\text { Ontario }\end{array}$ \\
\hline Gas Technology Institute/Shell & USA & Bangalore & $\begin{array}{l}\text { Residues, wood, stover, } \\
\text { bagasse, algae }\end{array}$ & Gasoline, jet, diesel & & Demonstration plant \\
\hline
\end{tabular}

Sources: The information presented above has been compiled from public sources, including periodicals, reports, company websites and communications with the industry, plus estimates based on all of those. 
While FT will always produce hydrocarbons in a range of lengths, the focus can be moved from long to short or vice versa, depending on feedstocks and process conditions (Figure 7).

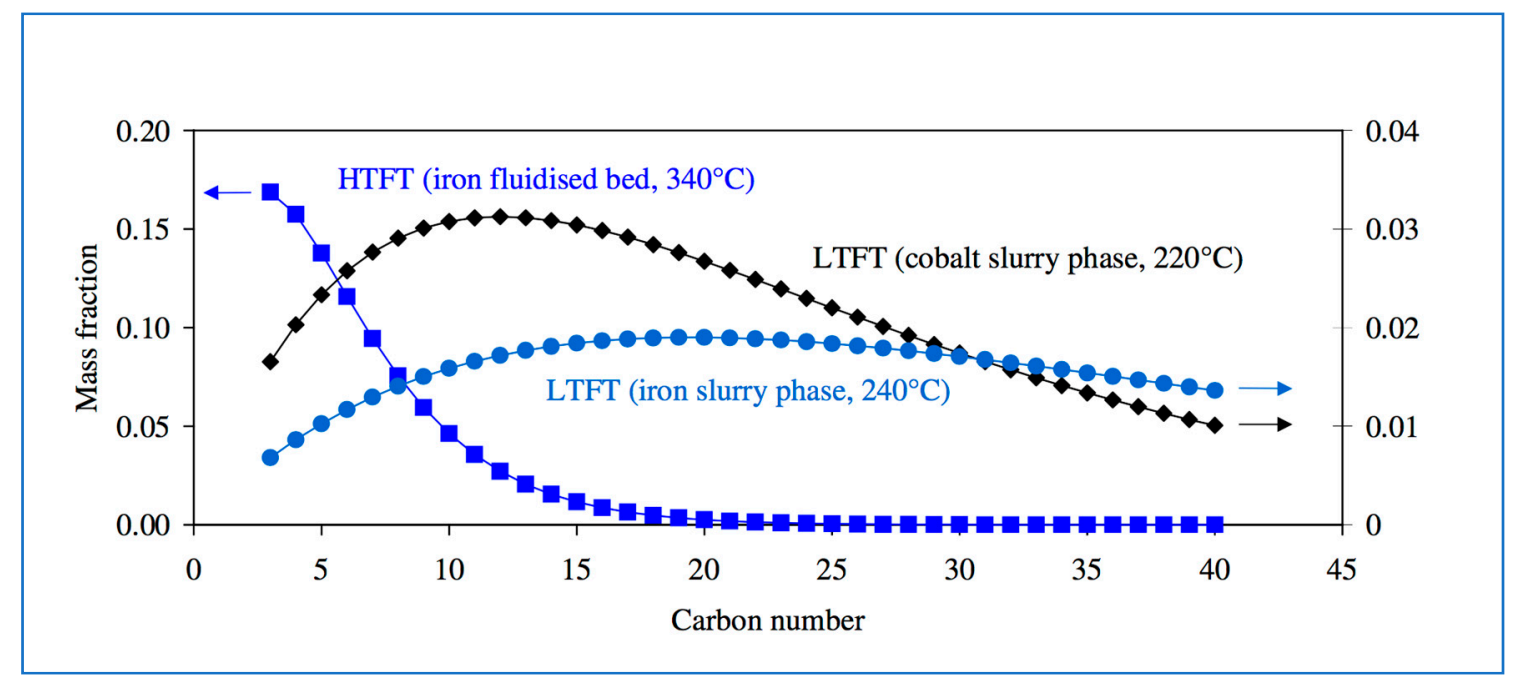

Figure 7. Products distributions for different coal-to-liquid FT processes, catalysts and reactors. Source: Atlantic Consulting.

FT synthesis is of syngas reacted over metallic catalysts to produce a mixture of longer-chain hydrocarbons. These can be upgraded via standard refinery processes (such as hydrocracking and distillation). FT plants can also generate excess electricity for sale to the grid. Overall yield, however, is very low. The Sasol coal-to-liquids plant's products are only $18 \%$ by weight on the incoming coal feedstock. For a biomass FT plant, the energy efficiency is only about $50 \%$ [18].

A Specific Fischer-Tropsch Process for Biomass to LPG: Japan Gas

Japan Gas Synthesis Co. Ltd. (Yokohama, Japan) and the University of Kitakyushu have developed a biomass gasification and FT process that maximises output of LPG. The work was part of a larger effort to synthesise DME, iso-paraffins, methanol and LPG using FT [20]. An overview of the LPG pathway was presented to an IEA Bioenergy conference in Vienna in 2012 [16].

The LPG concept was proven at laboratory scale. Japanese cedar wood was gasified to syngas: $49 \%$ carbon, $45 \%$ oxygen and the rest hydrogen. The syngas was reacted in one pass at $260{ }^{\circ} \mathrm{C}$ and 20 bar over a combination of catalysts: zeolites and commercial catalysts used for methanol synthesis. For $100 \mathrm{t}$ of wood input, the yield was $12.3 \mathrm{t}$ LPG plus around $12 \mathrm{t}$ of other off-gases (presumably other hydrocarbons).

In 2012, Japan Gas proposed to build a 100-200 t/day (36-72 kilotonne/year) commercial plant, based on this design. The proposal is not known to have been realised.

Syngas-to-Methanol (-to-Gasoline and LPG)

Another option for syngas is to convert it to methanol. This is less complex and costly than Fischer-Tropsch, and methanol is a fungible product that can be sold globally. Or, methanol can be converted to gasoline-which happens to produce LPG as a significant byproduct (Figure 8). This has been done with biomass at a demonstration scale, and with fossil feedstocks at a commercial scale. 


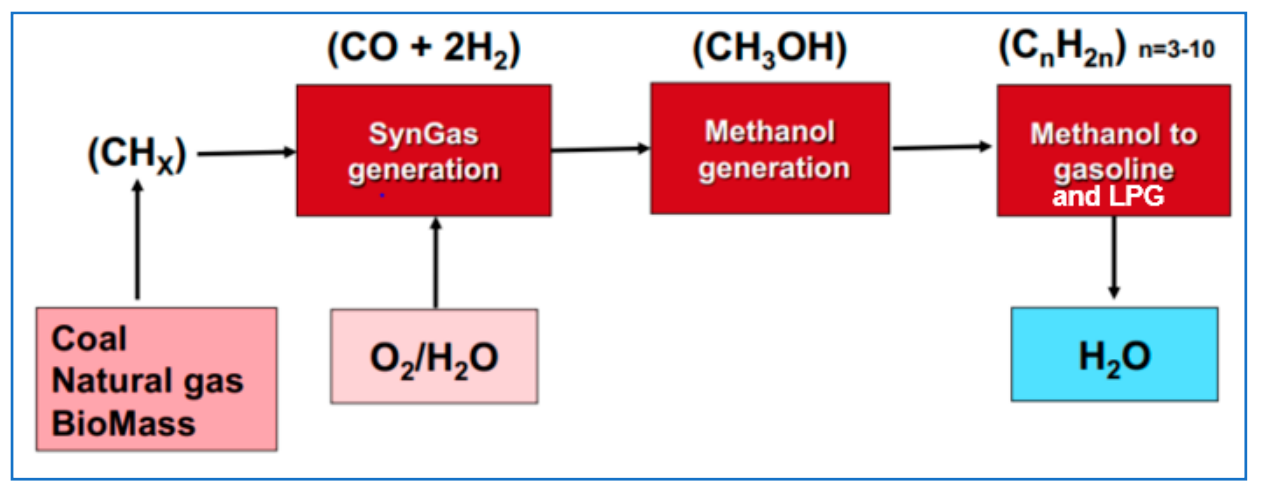

Figure 8. Schematic of the gas/coal/biomass-to-methanol-to-gasoline/LPG process. Source: ExxonMobil.

Most of the world's methanol is produced this way, but not from biomass, rather from 'stranded' natural gas (or sometimes coal), gas or coal that are too remote to be used locally or to be transported somewhere else. In most cases, the methanol is sold onward as methanol, but there are cases where it is converted on to gasoline and LPG:

- New Zealand: in 1985, the New Zealand government opened a commercial-scale natural-gas-tosyngas-to-methanol-to-gasoline plant, at Montuni, to exploit a natural gas field offshore. The process technology was supplied by Mobil, now ExxonMobil. Technically, the plant operated as planned, but the economics were unattractive, so as of 1997 it stopped making gasoline but continued making methanol—which it still does today (http://www.techhistory.co.nz/ThinkBig/ Petrochemical\%20Decisions.htm).

- China: in 2009, the Jincheng Anthracite Mining Group started up a commercial plant in Shanxi that follows the same process as in New Zealand, except starting with coal. A second, much-larger plant came onstream in 2017. Process technology was supplied by ExxonMobil.

- United States: the company G2X Energy is planning a world-scale methanol plant at Lake Charles, Louisiana, that it calls the Big Lake Fuels project. As of early 2018, the plant has been permitted, but not built. G2X has licensed ExxonMobil's methanol-to-gasoline process, but it is unclear if the project will be built, and if built, if it will include gasoline or just stop at methanol. ExxonMobil has also licensed its process to a company named DKRW Advanced Fuels, which planned to build a coal-to-methanol-to-gasoline plant near to a coal mine at Medicine Bow, Wyoming. The plant, announced in 2009, was to have started operation in 2014, but construction never started, due to lack of funding and permitting problems.

All of these run on syngas from fossil fuels: what about biomass to biogasoline and BioLPG? This has been proven at a demonstration scale. A 'Green Gasoline from Wood' project, funded mainly by the US Department of Energy and led by the Gas Technology Institute, ran from 2010-2014 at a plant in Des Plaines, Illinois. The methanol-to-gasoline section was supplied by Haldor Topsoe, with its TIGAS process. In the plant, wood chips are gasified to syngas, synthesised to methanol/DME and further reacted to naphtha (gasoline) and LPG (Figure 9). The LPG is about two-thirds butane, one-third propane.

The demonstration plant was fed about 19 tonnes/day of wood chips and produced 23 barrels/day of gasoline plus 3 barrels/day of LPG. Based on the demo plant results, the project delivered a conceptual design of a commercial-scale plant that would intake 2088 kilotonnes/year of wood at $50 \%$ moisture to produce $175 \mathrm{kt}$ of biogasoline and $16 \mathrm{kt}$ of BioLPG [21]. LPG yield is $8.4 \%$ by weight of the output. 


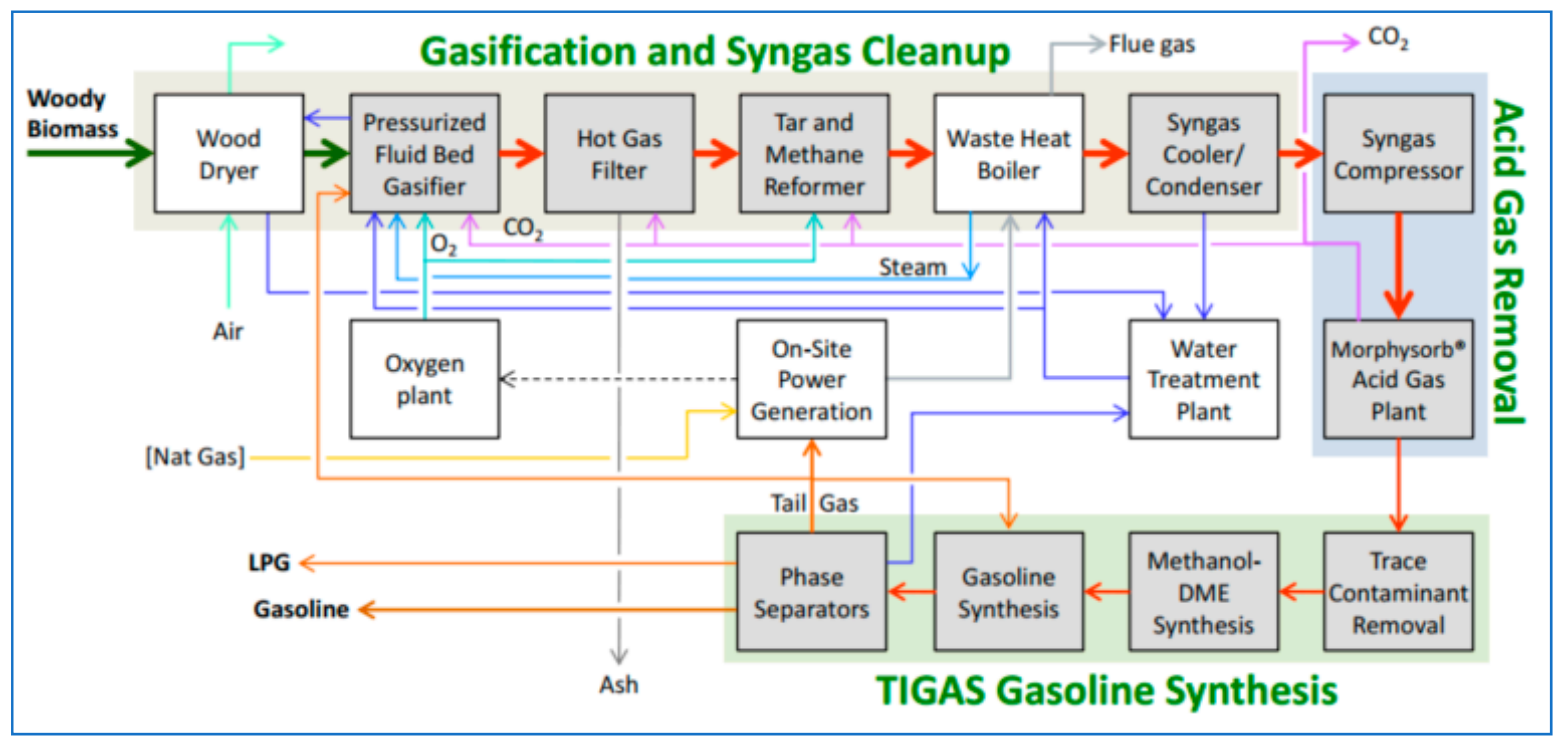

Figure 9. Schematic flow-sheet of the wood-to-gasoline/LPG demo plant 'green gasoline from wood'.

Will wood-to-biogasoline/BioLPG go commercial? Haldor Topsoe would surely license TIGAS to an interested operator, and so would ExxonMobil, which says its MTG process could be adapted to biomass feedstock [22]. These are the only known licensors of the process.

Which leaves the question of BioLPG yields? For coal feedstock, Exxon has reported yields of $10 \%$ butane, $5 \%$ propane plus another $1 \%$ butylenes, i.e., $16 \%$ LPG of the total output by weight. Haldor Topsoe has reported that its TIGAS process could be optimised to make 20-25\% LPG, but this seems to be for fossil feedstocks [23]. As a working figure, we estimate that the $8.4 \%$ proven at 'green gasoline' could be improved to $10 \%$.

Repurposed Methanol: Glycerine to BioLPG?

There is speculation that conventional methanol plants (which gasify natural gas to syngas and then react that syngas to methanol) could be repurposed to convert bioglycerine-which is massively available at low prices-to BioLPG.

The example is a company called Bio-MCN, which operates a plant in The Netherlands (Table 10) that gasifies glycerine and converts the syngas to methanol. It is a special case: an existing natural-gasto-methanol plant on the site was shut down, for economic reasons, and with heavy subsidy by the Dutch Government it was modified to run not on gas but on bioglycerin. Discussions with experts suggest that this plant could be further modified, with relative ease, to produce BioLPG instead of biomethanol.

If this is indeed feasible, it is a larger opportunity than just this plant. Methanol is a very cyclical business, and plants are regularly mothballed or shut for economic reasons. Moreover, methanol plants are sometimes moved from one location to another where the economics (i.e., natural gas prices) are more attractive. Converting them to BioLPG could be another option.

Synthetic Natural Gas (SNG)

The third relevant option for syngas-to-BioLPG is a variant of the process known as synthetic natural gas (SNG). It could be modified to produce BioLPG.

The name is confusing (is it synthetic or natural?), but what it means is bio-syngas converted to methane, which then is used in the same way as natural gas. Three projects have been identified (Table 10) based on cellulosic feedstocks, and another one is in development using mixed waste (see Section 4.4.3). SNG has been researched since at least the 1990s, but it has never reached 
commercialisation, because its economics have never been attractive enough. However, as some governments force bio or renewable content into their gas grids, its economics might turn attractive.

As the name suggests, SNG is aimed at methane. Nonetheless, discussions with developers suggest that the process could be modified to produce a combination of SNG and BioLPG. At present, no such research or development is known to be underway in this area.

Pyrolysis and Fast Hydropyrolysis (IH2)

A final gaseous conversion and synthesis option for BioLPG is a process that pyrolyzes cellulosic biomass and then synthesises those pyoils into liquid fuels. About 20 projects that pyrolyse and synthesise fuels from cellulosics have been identified (Table 10). None of those actually operating are believed to be of commercial-scale, although the Envergent project in Canada would be, if it is ever built.

Do they or will they produce BioLPG? Probably very little, if at all, with one exception: the IH2 process, developed by the Gas Technology Institute (GTI) and available for license through a Shell subsidiary company, CRI/Criterion, can produce biopropane at about $10 \%$ volume of the total output, presumably this is about $6 \%$ of the output by weight $[23,24]$. IH2 has been piloted a $50-\mathrm{kg} /$ day plant operated by GTI and at a 5-tonne/day plant operated by Zeton Inc in Ontario, Canada. A demonstration-sized unit has reportedly been built in Bangalore, India.

This process is two-staged: first a medium pressure, catalytic 'fast' hydropyrolysis in a fluid bed under moderate hydrogen pressure. The hydrogen comes from the back end of the process: low-value $C_{1}$ and $C_{2}$ hydrocarbons are steam-reformed to make the hydrogen. Intermediates from the first stage enter a hydroconversion step, where a hydrodeoxygenation catalyst removes remaining oxygen and produces gasoline, diesel, jet, and LPG. Because it is pyrolysis, there is some solid (char) produced as well.

\subsubsection{Gaseous Conversion and Synthesis, Mixed Wastes (Advanced Conversion Technologies)}

Gaseous conversion and synthesis can also be applied to mixed wastes, most notably municipal waste. In this application, such processes are known as Advanced Conversion Technologies (ACTs). ACTs can be appealing to waste-disposal authorities, who are keen to find alternatives to landfill (increasingly forbidden or restricted) and incineration (often opposed by local communities). ACTs are believed to emit fewer particulates and dioxins than ACTs, because they run at higher temperatures, and they can be built in smaller, less-obtrusive sizes [25].

ACTs are similar to their cousins that process cellulosics (see above). They gasify or pyrolyze the (waste) feedstock into syngas or pyoil. However, with a few exceptions, they do not turn that gaseous intermediate into a liquid product-typically they burn it in a gas engine or a gas turbine to generate electricity. Because it is classified as renewable power (although $20-40 \%$ of the hydrocarbons in municipal wastes are fossil based, mainly from plastics), government credits/funds for green electricity usually can be obtained. Ironically, ACTs are less energy-efficient at than conventional incinerators, which run at $18-32 \%$ efficiencies [26].

To date, ACTs have shown mixed results. Reportedly they work successfully in Japan, but in Europe, there have been several failures. Probably the best-known was an ACT planned for Teesside in the UK by Air Products that would have generated 100 MWatts of electricity. It was cancelled in 2016 while still under construction (https://www.ft.com/content/226c0e34-fb47-11e5-8f41-df5bda8beb40). Reportedly its problem and the problem of ACTs in general is their tendency to create tars in gasification/pyrolysis that go on to foul the back end of the process.

Nonetheless, municipal waste is not about to go away, so interest will probably persist. Numerous developers are pointing to plasma gasification as the possible solution to the tar problem [25,27]: this has yet to be proven. Moreover, interest will persist in turning the syngas/pyoil into fuels or chemicals. No ACT projects are known to be targeting LPG, but three projects are aimed at not-distant chemicals: 
- Enerkem, Alberta, Canada, waste-to-methanol: since 2014, this plant makes 30 kilotonnes/year of methanol from municipal waste in Edmonton. It is believed to be the first successful waste-tochemical plant.

- Enerkem and partners, Rotterdam, The Netherlands, waste-to-methanol: this is tentatively planned for around 2020. It would convert $360 \mathrm{kt} / \mathrm{year}$ of waste to $220 \mathrm{kt}$ of methanol. Partners include Air Liquide, Akzo Nobel, and the Port of Rotterdam.

- GoGreenGas, UK, waste-to-synthetic-natural-gas: the company owned mainly by Cadent, the UK's gas grid operator, has pilot tested a process and is now planning to go to commercial scale. The SNG would be input to the gas grid.

How does this relate to BioLPG? Although no work is known to be going on in this direction, the above processes probably could be modified to produce LPG, waste volumes are of course huge, and waste as a feedstock has an inherent economic-incentive of a gate fee.

\subsubsection{Liquid Conversion and Synthesis}

A final option for BioLPG is liquid conversion and synthesis: about 15 projects that apply this process type to cellulosics have been identified (Table 11). None of those are of significant scale or commercial significance to BioLPG. If bio-pyrolysis oil were to be produced in significant quantities, refining it presumably could produce similar proportions of BioLPG as conventional refineries make of LPG, around $5 \%$ by weight.

Earlier this decade, there was an effort in the direction of BioLPG. Researchers at the Massachusetts Institute of Technology in the USA reportedly developed a process for converting starch/sugar from corn or sugarcane to propane. A company, C3 BioEnergy, was formed to commercialise the technology [8], but the company apparently was not able to pursue this and no longer exists.

Table 11. Liquid conversion and synthesis projects for BioLPG, by owner/operator.

\begin{tabular}{|c|c|c|c|c|c|}
\hline Owner/Operator & Country & Feedstock(s) & Prime Product & $\begin{array}{l}\text { Prime Product } \\
\text { Capacity kt/y }\end{array}$ & Source \\
\hline Altaca/SCF Technologies & $\mathrm{T}$ & $\begin{array}{l}\text { Sewage sludge, } \\
\text { food waste }\end{array}$ & Bio-crude & 7.098 & Author research \\
\hline $\begin{array}{l}\text { Biochemtex/ETH Zürich/KLM } \\
\text { (Dutch national airline)/RE-CORD } \\
\text { (Italian university consortium) }\end{array}$ & I & Lignin & Jet & 1.95 & $\begin{array}{l}\text { https://www.biorefly.eu/project- } \\
\text { partners }\end{array}$ \\
\hline Chalmers University & $S$ & Lignin & Bio-crude & 0 & Author research \\
\hline Chemtex & USA & Lignin & Bio-crude & 0 & Author research \\
\hline $\begin{array}{l}\text { Genifuel/Pacific Northwest } \\
\text { National Laboratory }\end{array}$ & USA & $\begin{array}{l}\text { Wastes, algae, } \\
\text { wood, straws }\end{array}$ & Bio-crude & 0.2496 & $\begin{array}{l}\text { http://www.genifuel.com/ } \\
\text { technology.html }\end{array}$ \\
\hline Licella & AUS & $\begin{array}{l}\text { Wood, energy } \\
\text { crops, algae }\end{array}$ & Bio-crude & 15.522 & Author research \\
\hline Muradel & AUS & Micro-algae & Bio-crude & 0.0156 & https://muradel.com.au \\
\hline Next Fuels & NL & Palm waste & Bio-crude & 0.3276 & \\
\hline $\begin{array}{l}\text { Pacific Northwest National } \\
\text { Laboratory }\end{array}$ & USA & $\begin{array}{l}\text { Lignocellulosics, } \\
\text { algae }\end{array}$ & Bio-crude & 0 & Author research \\
\hline Research Triangle Institute & USA & Lignocellulosics & Bio-crude & 0.0234 & Author research \\
\hline Shell HTU & NL & $\begin{array}{l}\text { Wastes, wood, } \\
\text { residues }\end{array}$ & Bio-crude & 0.039 & Author research \\
\hline Southern Oil Refining & AUS & Bio-crude & Diesel, jet & 0.2574 & $\begin{array}{l}\text { https://www.biofuelsdigest.com/ } \\
\text { bdigest/tag/southern-oil-refining/ }\end{array}$ \\
\hline Steeper Energy/Aalborg Uni & DK & $\begin{array}{l}\text { DDGS, peat, } \\
\text { wood, tall oil }\end{array}$ & Bio-crude & 0.0156 & Author research \\
\hline Virent & USA & $\begin{array}{c}\text { Glycerol, } \\
\text { sugars, starches }\end{array}$ & Bio-crude & & $\begin{array}{l}\text { http://www.virent.com/ } \\
\text { technology/bioforming/ }\end{array}$ \\
\hline
\end{tabular}

Sources: The information presented above has been compiled from public sources, including periodicals, reports, company websites and communications with the industry, plus estimates based on all of those.

\section{Other: Atmospheric Carbon Dioxide}

A final route to LPG is the process of reacting carbon dioxide from the atmosphere with 'renewable' hydrogen to create LPG. Ambient carbon dioxide can be absorbed directly from the air or from 
combustion exhausts (from, say, a power plant). Renewable hydrogen can be made by hydrolysis of water, using low-carbon electricity powered by hydro, solar or wind energy.

Seven companies are known to be pursuing this. They are not targeting LPG, rather higherhydrocarbon fuels (Table 12). Still, they could in principle also pursue LPG. Not much detail is public about their processes, but presumably they are creating a syngas and then from that synthesizing fuels. Production so far is no more than laboratory scale, yet Carbon Engineering and Nordic Blue Crude claim to be pursuing commercial-scale plants.

Table 12. Companies pursuing atmospheric-carbon-to-fuels.

\begin{tabular}{ccc}
\hline Owner/Operator & Location(s) & Country \\
\hline Audi & Laufenberg & $\mathrm{CH}$ \\
Carbon Engineering & British Col. & $\mathrm{CAN}$ \\
Climeworks & Zürich & $\mathrm{CH}$ \\
New $\mathrm{CO}_{2}$ Fuels & Rehovot & ISR \\
Nordic Blue Crude & Herøya & $\mathrm{N}$ \\
SOLETAIR & Lappeenranta & $\mathrm{SF}$ \\
Sunfire & Dresden & $\mathrm{D}$
\end{tabular}

Source: Author research and www.chemistryworld.com/business/carbon-capture-from-air-goes-commercial/ 3007813.article.

Would these generate biofuels? Not as such. Water is not bio; it is considered an inorganic, non-biological resource. Of atmospheric carbon dioxide, only about one-quarter is biological, the rest is inorganic. So, these fuels would be renewable, but not biological. Therefore, this process is classed for now as 'other'.

\section{Conclusions}

BioLPG has been commercialized to offer the LPG industry a route to decarbonisation. Production is now around 200 thousand tonnes annually. Although this is a relatively small fraction of some 300 million tonnes of LPG sold annually, it is important, because it offers the LPG industry and its customers a bio-alternative to match its competitors and to demonstrate its 'bio credibility' to governments.

Clearly, to maintain and build this bio-credibility, BioLPG needs to be produced in greater volumes and probably via multiple processes. This article gives a scientific basis to that effort, by documenting all known process routes and relevant projects.

BioLPG can be produced by seven general processes (Table 1). Two of them are most promising:

- Hydrotreating of bio-oils is already producing 200 kilotonnes of biopropane, with some additions planned

- Gaseous conversion and synthesis of cellulosics and organic waste does not yet generate any BioLPG, but BioLPG production this way is technically feasible, is under exploration and potential feedstock availability is huge.

Dehydrogenation offers some potential, mainly in the use of fluid catalytic crackers to process bio-oils and make some byproduct biopropane. Glycerine also can be dehydrogenated, and this is being explored. Fermentation already is producing small amounts of biobutylene, and planning in underway for commercial production.

Fermentation to biopropane has been proven at laboratory scale, but does not seem to be progressing further. The two other biological process classes, hydrolysis and fermentation and digestion, do not offer serious promise of generating BioLPG. Neither does liquid conversion and synthesis, which technically is not all that different than gaseous conversion and synthesis, but attracts significantly less attention from developers. 
Funding: This research was funded by Atlantic Consulting.

Conflicts of Interest: The authors declare no conflict of interest.

\section{References}

1. Johnson, E. New biofuel debut: Biopropane. Biofuels Bioprod. Biorefin. 2015, 9, 627-629. [CrossRef]

2. Soucek, I.; Popovic, Z.; Koprivsek, V. Alternative Bio-Diesel Production. Available online: https://www. researchgate.net/publication/272237992_Alternative_Bio-Diesel_Production (accessed on 13 January 2019).

3. Natural Resources Canada. Study of Hydrogenation Derived Renewable Diesel as a Renewable Fuel Option in North America; Natural Resources Canada: Ottawa, ON, Canada, 2012. Available online: https://www.nrcan.gc.ca/sites/www.nrcan. gc.ca/files/oee/files/pdf/transportation/alternative-fuels/resources/pdf/HDRD_Final_Report_eng.pdf (accessed on 13 January 2019).

4. Engman, A.; Hartikka, T.; Honkanen, M.; Kiiski, U.; Kuronen, M.; Lehto, K.; Mikkonen, S.; Nortio, J.; Nuottimäki, J. Neste Renewable Diesel Handbook; Neste: Helsinki, Finland, 2016. Available online: https: //www.neste.com/sites/default/files/attachments/neste_renewable_diesel_handbook.pdf (accessed on 13 January 2019).

5. Topsoe, H.; Egeberg, R.G.; Michaelsen, N.H.; Skyum, L. Novel Hydrotreating Technology for Production of Green Diesel; Haldor Topsoe: Lyngby, Denmark, 2010. Available online: https://www.topsoe.com/sites/default/files/ novel_hydrotreating_technology_for_production_of_green_diesel.ashx_.pdf (accessed on 13 January 2019).

6. De Paz Carmona, H.; Horáček, J.; Brito Alayón, A.; Macías Hernández, J.J. Suitability of used frying oil for co-processing with atmospheric gas oil. Fuel 2018, 214, 165-173. [CrossRef]

7. NREL-National Renewable Energy Laboratory. Bio-Propane: Production Pathways and Preliminary Economic Analysis; NREL: Golden, CO, USA, 2018.

8. UK Department of Energy \& Climate Change; Atlantic Consulting; Menecon Consulting. RHI Evidence Report: Biopropane for Grid Injection; UK Department of Energy \& Climate Change: London, UK, 2014. Available online: https://assets.publishing.service.gov.uk/government/uploads/system/uploads/attachment_data/file/ 376487/RHI_Evidence_Report_-_Biopropane_for_Grid_Injection_2__2_.pdf (accessed on 13 January 2019).

9. Brandin, J.; Hulteberg, C.; Nilsson, A. Bio-Propane from Glycerol for Biogas Addition; S Svenskt Gastekniskt Center AB: Malmö, Sweden, 2008.

10. Renewable Energy Group. Renewable Propane: Current Production and Future Outlook; Renewable Energy Group: Ames, IA, USA, 2017.

11. E4tech. Advanced Drop -In biofuels UK Production Capacity Outlook to 2030 Final Report; E4Tech: London, UK, 2017. Available online: https:/assets.publishing.service.gov.uk/government/uploads/system/uploads/ attachment_data/file/652538/advanced-drop-in-biofuels-uk-production-capacity-outlook-2030.pdf (accessed on 13 January 2019).

12. Global Bioenergies; Anissimova, M. Production of Bio-Propylene by Fermentation; Global Bioenergies: Evry, France, 2015.

13. Kallio, P.; Pásztor, A.; Thiel, K.; Akhtar, M.K.; Jones, P.R. An engineered pathway for the biosynthesis of renewable propane. Nat. Commun. 2014, 5, 4-11. [CrossRef] [PubMed]

14. Menon, N.; Pásztor, A.; Menon, B.R.K.; Kallio, P.; Fisher, K.; Akhtar, M.K.; Leys, D.; Jones, P.R.; Scrutton, N.S. A microbial platform for renewable propane synthesis based on a fermentative butanol pathway. Biotechnol. Biofuels 2015, 8, 1-12. [CrossRef] [PubMed]

15. Kumar, M.; Olajire Oyedun, A.; Kumar, A. A review on the current status of various hydrothermal technologies on biomass feedstock. Renew. Sustain. Energy Rev. 2018, 81, 1742-1770. [CrossRef]

16. Ogi, T.; Nakanishi, M.; Fujimoto, K. Synthesis of Bio-LPG from Biomass-derived Syngas. In Proceedings of the IEA Bioenergy Conference, Vienna, Austria, 13-15 November 2012; p. 23.

17. NREL—National Renewable Energy Laboratory; Spath, P.L.; Dayton, D.C. Preliminary Screening-Technical and Economic Assessment of Synthesis Gas to Fuels and Chemicals with Emphasis on the Potential for Biomass-Derived Syngas; NREL: Golden, CO, USA, 2003.

18. Larson, E.; Jin, H. Biomass Conversion to Fischer-Tropsch Liquids: Preliminary Energy Balances. In Proceedings of the 4th Biomass Conference of the Americas, Oakland, CA, USA, 29 August-2 September 1999; p. 6.

19. Bechtel. Baseline Design/Economics for Advanced Fischer-Tropsch Technology; Bechtel: Pittsburgh, PA, USA, 1998. 
20. Fujimoto, K. Synthetic fuels from synthesis gas activities in Japan. Proc. ACS Div. Fuel Chem. 2004, 49, 700-701.

21. US Department of Energy. Green Gasoline from Wood Using Carbona Gasification and Topsoe TIGAS Processes; US Department of Energy: Washington, DC, USA, 2015. Available online: https://www.osti.gov/servlets/purl/ 1173129 (accessed on 13 January 2019).

22. Hindman, M. ExxonMobil Methanol to Gasoline. In Proceedings of the Syngas Technology Conference, Colorado Springs, CO, USA, 15-18 October 2017; p. 24.

23. Gas Technology Institute. Synthetic and Bio-LPG, Expert Analysis of the Concept of PERC; Gas Technology Institute: Des Plaines, IL, USA, 2010.

24. Gas Technology Institute. IH2 Process; Gas Technology Institute: Des Plaines, IL, USA, 2014.

25. Eunomia. Investment in Advanced Conversion Technologies: Has the Time Finally Arrived? Eunomia: Bristol, UK, 2016. Available online: https://www.eunomia.co.uk/reports-tools/investment-in-advanced-conversiontechnologies-act/ (accessed on 13 January 2019).

26. International Solid Waste Association. Alternative Waste Conversion Technologies: White Paper; ISWA: Copenhagen, Denmark, 2013. Available online: https:/www.iswa.org/home/news/news-detail/browse/29/ article/new-publication-iswa-white-paper-on-alternative-waste-conversion-technologies/109 (accessed on 13 January 2019).

27. Farzad, S.; Mandegari, M.A.; Görgens, J.F. A critical review on biomass gasification, co-gasification, and their environmental assessments. Biofuel Res. J. 2016, 3, 483-495. [CrossRef]

(C) 2019 by the author. Licensee MDPI, Basel, Switzerland. This article is an open access article distributed under the terms and conditions of the Creative Commons Attribution (CC BY) license (http://creativecommons.org/licenses/by/4.0/). 